\title{
Current evidence and applications of photodynamic therapy in dermatology
}

\section{Citation}

Wan, Marilyn T., and Jennifer Y Lin. 2014. "Current evidence and applications of photodynamic therapy in dermatology." Clinical, Cosmetic and Investigational Dermatology 7 (1): 145-163. doi:10.2147/CCID.S35334. http://dx.doi.org/10.2147/CCID.S35334.

\section{Published Version}

doi:10.2147/CCID.S35334

\section{Permanent link}

http://nrs.harvard.edu/urn-3:HUL.InstRepos:12406780

\section{Terms of Use}

This article was downloaded from Harvard University's DASH repository, and is made available under the terms and conditions applicable to Other Posted Material, as set forth at http:// nrs.harvard.edu/urn-3:HUL.InstRepos:dash.current.terms-of-use\#LAA

\section{Share Your Story}

The Harvard community has made this article openly available.

Please share how this access benefits you. Submit a story.

\section{Accessibility}




\section{Current evidence and applications of photodynamic therapy in dermatology}

\author{
Marilyn TWan' \\ Jennifer $Y \operatorname{Lin}^{2}$ \\ 'Melanoma Program, Dana-Farber \\ Cancer Institute, ${ }^{2}$ Department of \\ Dermatology, Brigham and Women's \\ Hospital, Harvard Medical School, \\ Boston, MA, USA
}

This article was published in the following Dove Press journal:

Clinical, Cosmetic and Investigational Dermatology

2I May 2014

Number of times this article has been viewed

\begin{abstract}
In photodynamic therapy (PDT) a photosensitizer - a molecule that is activated by light - is administered and exposed to a light source. This leads both to destruction of cells targeted by the particular type of photosensitizer, and immunomodulation. Given the ease with which photosensitizers and light can be delivered to the skin, it should come as no surprise that PDT is an increasingly utilized therapeutic in dermatology. PDT is used commonly to treat precancerous cells, sun-damaged skin, and acne. It has reportedly also been used to treat other conditions including inflammatory disorders and cutaneous infections. This review discusses the principles behind how PDT is used in dermatology, as well as evidence for current applications of PDT.

Keywords: photodynamic therapy, skin cancer, actinic keratosis, acne, aminolevulinic acid,
\end{abstract} methylaminolevulinate

\section{Introduction}

Photodynamic therapy (PDT) is a therapeutic method used with increasing frequency in dermatology. In the US, PDT is approved for the treatment of thin actinic keratoses, but off-label uses continue to increase. ${ }^{1}$ The concept of PDT is deceptively simple, in that it requires only three ingredients, ie, a photosensitizer, a light source, and oxygen. The therapeutic effect is achieved by light activation of a photosensitizing agent, and in the presence of oxygen, reactive oxygen intermediates are formed. These intermediates irreversibly oxidize essential cellular components, causing apoptosis and necrosis., ${ }^{2,3}$ PDT is safe and effective, and produces excellent cosmetic results with few adverse effects. It has the advantage of allowing application to multiple lesions. Pain, edema, erythema, pigmentation, and pustules are among the main complications, with the most common complaint being pain during delivery of treatment. ${ }^{4,5}$ In this paper, we review the evidence for current applications of PDT in dermatology.

\section{History}

At the beginning of the 20th century, Oscar Raab, a medical student, serendipitously discovered the toxic effect of cumulative acridine orange (a photosensitizer) and light on Paramecium caudatum cells. He confirmed his findings by testing the components individually, with no apparent damaging effect on the protozoa separately. His professor, Von Tappeiner, worked in collaboration with Jesionek, a dermatologist, on the first clinical trial, which was conducted in 1903 using eosin and light to treat the cutaneous manifestations of diseases such as condylomata lata, lupus vulgaris, psoriasis, stage II syphilis, and non-melanoma skin cancer. ${ }^{6,7}$ Von Tappeiner referred to this as "photodynamic therapy". ${ }^{8,9}$ Despite this breakthrough, PDT was not widely used until
Correspondence: Jennifer $Y$ Lin Department of Dermatology, Brigham and Women's Hospital, Harvard Medical School, Boston, MA 02115, USA

Tel+l 6172645943

Email jylin@partners.org 
the mid 1970s. For example, in 1975, Thomas Dougherty discovered that administration of a hematoporphyrin derivative and red light obliterated mammary tumor growth in mice. ${ }^{10}$

\section{Mechanism}

PDT requires three essential components: a photosensitizer, a light source, and oxygen. The photosensitizer is a molecule that localizes to the target cell and/or tissue and can only be activated by light. When the photosensitizer is exposed to specific wavelengths of light, it becomes activated from a "ground state" to an "excited state" (Figure 1). As it returns to the ground state, there are two ways in which the energy released can mediate selective cell killing. First, it can react with the substrate to form radicals, which further interact with oxygen to produce oxygen free radicals (type I reaction). Or the energy can be directly transferred to oxygen to form singlet oxygen $\left({ }^{1} \mathrm{O}_{2}\right)$, a subset of reactive oxygen species, which then oxidizes various substrates (type II reaction) and thus mediates selective cell killing. ${ }^{3}$ Type II photochemical reactions are thought to predominate in PDT. ${ }^{11}$ Damage to surrounding healthy tissue can be minimized by modifying the selectivity of uptake and directing the duration and depth of the light source. Selectivity of PDT is determined by several factors, including: uptake of the photosensitizer into target cells/tissue; metabolism of the agent to its active form; and penetration and selectivity of the light source. Given these variables, the clinical reaction for each individual can be difficult to predict.

Phototoxic effects occur through intracellular localization of the photosensitizer and surrounding immunologic effects.
Porphyrins are mainly localized in mitochondria, that lead to apoptosis or necrosis upon light exposure..$^{712-14}$ Immunespecific responses include production of interleukin 1-beta, interleukin 2, tumor necrosis factor-alpha, and granulocyte colony-stimulating factor. PDT generally has a low potential for causing DNA damage, mutation, or carcinogenesis. ${ }^{15}$

\section{Clinical delivery Photosensitizers}

There are many types of photosensitizers available and several routes (topical, oral, or intravenous) by which they can be delivered to the patient. Currently, the only photosensitizers approved by the US Food and Drug Administration for dermatologic indications are aminolevulinic acid (ALA) and methyl aminolevulinate (MAL). Both drugs are prodrugs that require conversion to porphyrin. After topical application of the photosensitizer, an "occlusion time" is permitted for the drug to be metabolized and accumulate porphyrins before light activation. Ultimately, porphyrin serves as the photosensitizer.

Most cells in the human body can metabolize ALA or MAL into photoactivatable porphyrins, in particular protoporphyrin IX, but the levels vary between tissue and cell types. For example, porphyrins accumulate mostly in sebaceous glands and in the epidermis and preferentially in dysplastic cells and hyperproliferative tissue. ${ }^{16-18}$ The main barrier to the absorption of photosensitizers is the stratum corneum. ${ }^{19}$ ALA crosses the cell membrane, and conversion to protoporphyrin IX occurs intracellularly. However ALA esters, such as MAL, are first hydrolyzed to ALA in

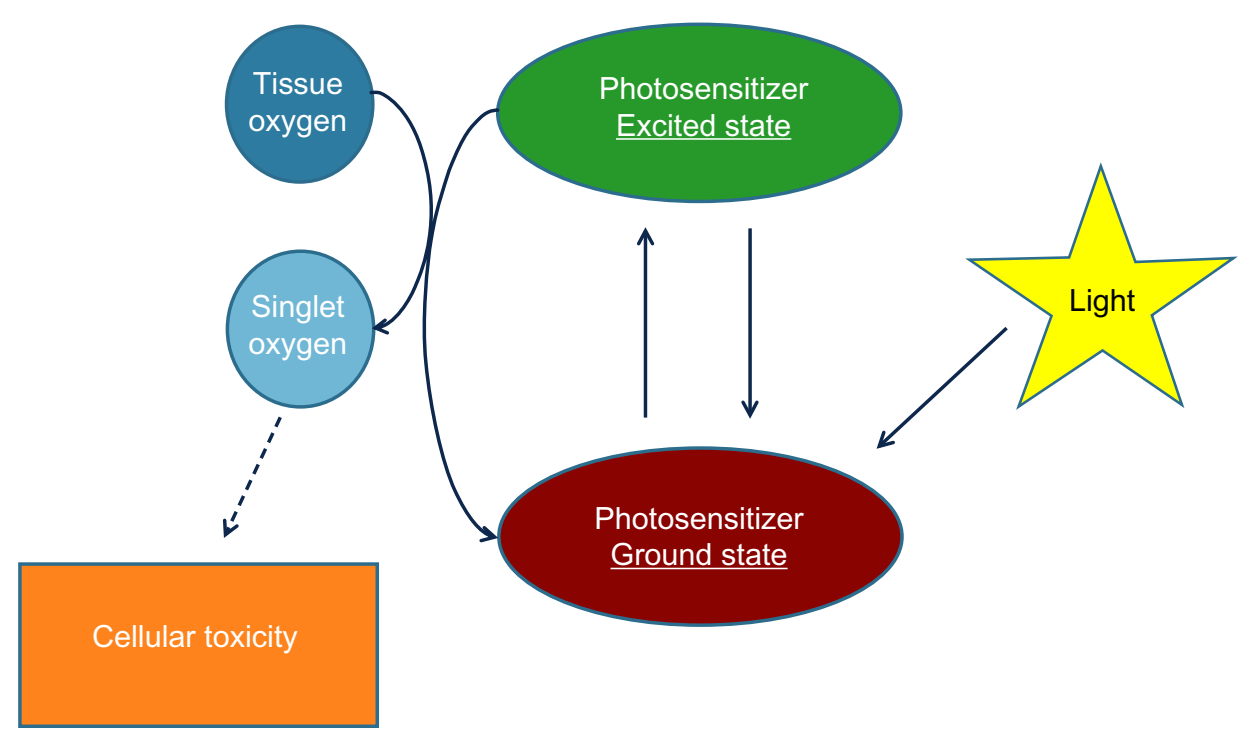

Figure I Schema of a photochemical reaction during photodynamic therapy. Absorption of photons from a light source results in energy transfer to the photosensitizer. The photosensitizer moves from a ground state to an excited state. The energy released (as it returns to ground state) mediates cellular cytotoxicity. 
the cytosol. ALA is then converted to protoporphyrin IX physiologically as part of the heme cycle. ${ }^{20}$ This extra conversion is thought to result in a delay in onset of MAL photosensitization, and therefore the incubation period for MAL needs to be longer. Additional factors, such as temperature, also affect the efficiency of protoporphyrin IX production in that higher temperatures facilitate conversion. ${ }^{21}$ Quenching of the existing photosensitizer is known as photobleaching, which results in what is visualized as fluorescence. For instance, using a camera with a filter for excitation (415 nm) and a filter for emission $(635 \mathrm{~nm})$ allows detection of the amount of photosensitizer in the tissue (Figure 2). The intensity of

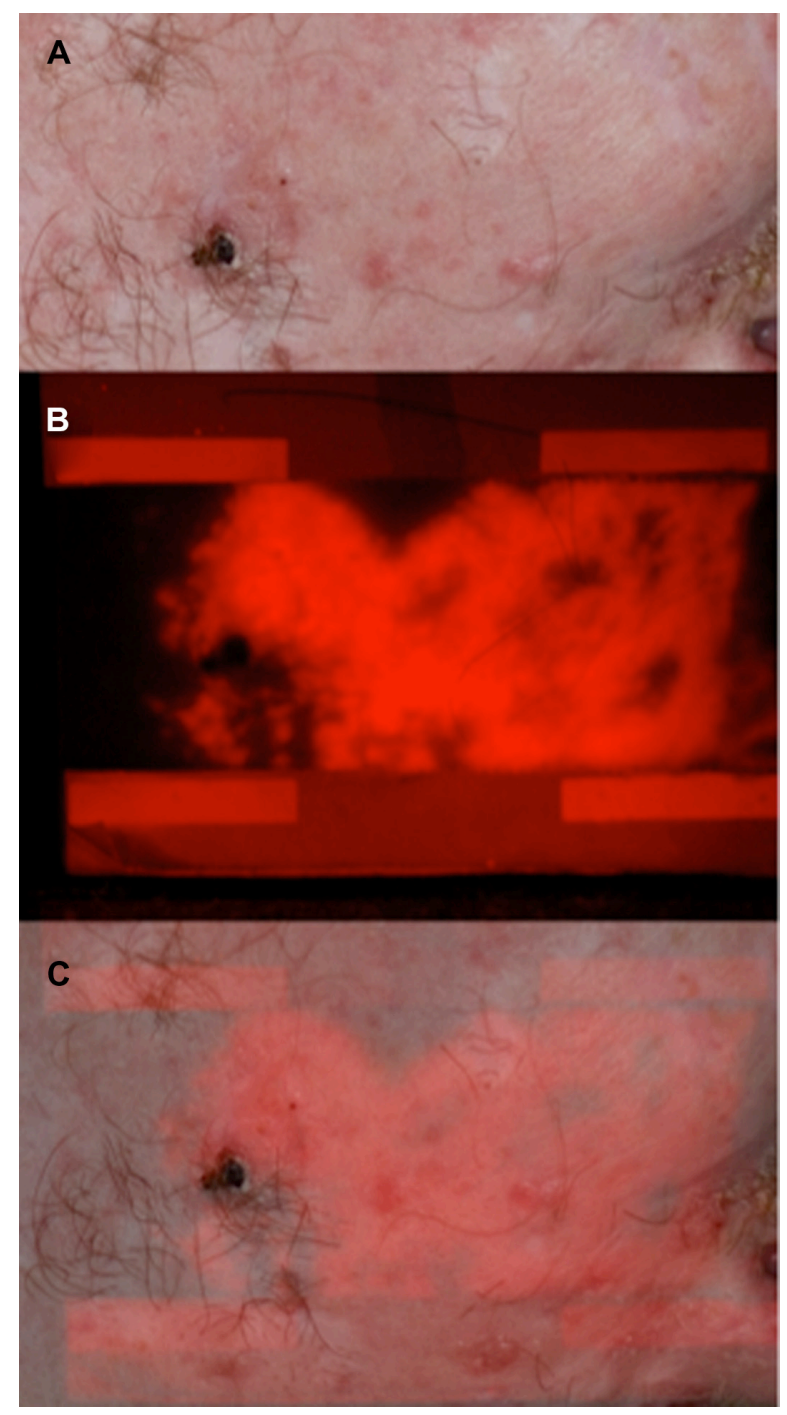

Figure 2 (A) Digital photograph of facial skin from a patient with nevoid basal cell carcinoma (Gorlin-Goltz) syndrome. (B) Fluorescence photography using $\sim 510 \mathrm{~nm}$ excitation and $\sim 633 \mathrm{~nm}$ emission filters after 3 hours of incubation with 5-aminolevulinic acid under occlusion. (C) Overlap of (A and $\mathbf{B}$ ) to highlight porphyrin accumulation in red. Note intense epidermal fluorescence beyond clinical tumor margins. Images courtesy of Fernanda H Sakamoto and R Rox Anderson, Wellman Center for Photomedicine, Massachusetts General Hospital, Harvard Medical School, Boston, MA, USA. the measured fluorescence represents photosensitizer uptake and, correspondingly, can predict PDT tissue damage. In the future, utilization of such technology may help clinicians to determine the parameters for PDT (for example, length of incubation or fluence delivered from the light source). ${ }^{22}$

\section{Aminolevulinic acid}

The only approved indication for ALA (Levulan ${ }^{\circledR}$, DUSA Pharmaceuticals Inc) is for the treatment of hypertrophic actinic keratoses on the face and scalp in combination with blue light in North America. In Europe, a patch containing ALA (Alacare ${ }^{\circledR}$, Spirig Pharma AG, Egerkingen, Switzerland) and a gel formulation ALA with nanoemulsion (Ameluz ${ }^{\circledR}$, Spirit Healthcare Ltd, Oadby, UK) are also licensed for treatment in combination with red light. ALA is unstable as an aqueous formulation because it has low lipid solubility, limiting its ability to penetrate through skin or cell membranes and thus restricting its use in PDT to superficial disease. ${ }^{23}$ One study demonstrated that ALA was able to penetrate up to $2 \mathrm{~mm}$ deep in nodular basal cell carcinoma (BCC). ${ }^{17}$ Novel preparations of ALA, particularly the nanoscale vesicle formulation, have been shown to chemically stabilize the drug and increase liposomal penetration. For instance, nanoemulsion/nanocolloidal formulations of this drug have been observed to be superior to methyl ester methyl aminolevulinate in the treatment of actinic keratoses (complete clearance $78.2 \%$ versus $64.2 \%$, respectively) and field cancerization. ${ }^{24-26}$ In Europe, BF-200 ALA (an approved nanoemulsion formulation of 5-ALA) has been studied extensively.

\section{Methyl aminolevulinate}

A derivative of ALA, methyl ester methyl aminolevulinate, MAL (Metvixia ${ }^{\circledR}$, Galderma SA, Lausanne, Switzerland) is available in a cream form and is approved in the US for the treatment of nonhyperkeratotic actinic keratoses of the face and scalp in immunocompetent patients. MAL (Metvix ${ }^{\circledR}$, Galderma SA) is also approved in several European countries, New Zealand, and Australia for both superficial and nodular BCC. MAL is also approved in Europe for squamous cell carcinoma (SCC) in situ, also known as Bowen's disease, when surgical excision is considered less appropriate, including for cosmetic purposes.

MAL is reported to have increased lipophilicity and deeper skin penetration when compared with ALA. However, there was no statistically significant difference in efficacy between ALA and MAL in the treatment of nodular BCC in one small pilot study or in the treatment of actinic keratosis 
in another randomized trial. ${ }^{27-29}$ In theory, MAL may be more selective than ALA in its affinity for lipophilic environments such as sebum, and thus would be predicted to have greater efficacy in the treatment of acne. ${ }^{18}$

Other ALA derivatives are the subject of ongoing research. Long-chain esters, such as heptyl esters, are capable of achieving the same protoporphyrin IX fluorescence induction at much lower concentrations than pure ALA. ${ }^{30}$ Further, several new photosensitizers (hypericin, indocyanine green, and indole-3-acetic acid) have been assessed in cutaneous oncologic diseases and are in the commercial pipeline. ${ }^{31-36}$

\section{Light source and methods of delivery}

The range of light sources is virtually limitless, and includes broad-spectrum continuous-wave light sources (blue, red, green light), incoherent polychromatic sources (gas discharge lamps, light-emitting diodes) or coherent monochromatic sources (intense pulsed light [IPL], potassium titanyl phosphate lasers, pulsed dye lasers, infrared lasers), PDT, photopneumatic technology, and daylight have all been studied.

To generate a therapeutic effect, the spectral output of the light source should correspond to the excitation peaks of the photosensitizer. Protoporphyrin IX has two important peaks, 404-420 nm and $635 \mathrm{~nm}$ in the blue (Soret band) and red wavelength regions of the visible spectrum, respectively. The US Food and Drug Administration has approved the Blu- $\mathrm{U}^{\circledR}$ (Blue Light Photodynamic Therapy Illuminator Model 4170, DUSA Pharmaceuticals Inc, Wilmington, MA, USA) device, which emits blue wavelengths of the light spectrum for use with ALA and other devices, including the red light spectral output to be used in conjunction with MAL. The depth of light penetration into the skin increases with longer wavelengths. Although blue light allows sufficient tissue penetration for the treatment of thin actinic keratoses, red light penetrates deeper and is more effective for the treatment of thicker lesions and deeper targets such as the sebaceous gland.

In comparison trials, employing continuous wave light sources is more efficacious than pulsed light sources. ${ }^{37}$ Increasingly, white light sources, including direct sunlight, have also been utilized. ${ }^{38-43}$ In one careful study of MAL-PDT in the treatment of actinic keratoses, with long-term followup, a light-emitting diode was the more effective light source as compared with white light. ${ }^{44}$ Nonetheless, an interesting avenue of research involves utilizing sunlight as the light source, which has the advantage of being accessible and does not occupy office space. The main advantage of using sunlight is the reduction in pain, given that photoactivation takes place over a longer period of time. Recent studies suggest that sunlight is effective as a light source for the treatment of actinic keratosis. ${ }^{41}$

Preparatory steps, particularly in the treatment of hypertrophic actinic keratoses, can improve photosensitizer uptake. The most recent studies include use of keratolytics, curettage/ debulking, tape stripping, microdermabrasion, and laser ablation. . $^{2,45,46}$ One split-face study demonstrated slightly superior efficacy and long-term improvement of actinic keratoses when using microneedling as a delivery system. ${ }^{47}$ Use of microneedling in SCC in situ and BCC failed to demonstrate either increased fluorescence uptake or clinical superiority. Nonetheless, SCC in situ and BCC are lesions that may not derive additional benefit from surface preparation, given their already compromised surface. Another study from Denmark demonstrated that use of a fractionated $\mathrm{CO}_{2}$ laser and PDT was significantly more effective than PDT alone at 3-month follow-up for all grades of severity in actinic keratosis. ${ }^{48}$

\section{Contraindications and side effects}

Contraindications to PDT include a nonresponsive tumor, a history of porphyria, systemic lupus erythematosus, photosensitive dermatoses, and allergy to the active ingredients in the photosensitizer, which is considerably rare.

Common side effects of PDT include erythema, edema, itching, epithelial exfoliation, pustules, and postinflammatory hyperpigmentation, especially for Fitzpatrick skin phototype IV-V. ${ }^{49}$ The most common complaint from patients is pain during administration of phototherapy. ${ }^{50-52}$ Some pain studies have indicated that ALA induces more pain as compared with MAL, while others have assessed the pain to be similar between the two photosensitizers. ${ }^{28,53,54}$

\section{PDT in neoplastic disease}

\section{Actinic keratoses}

Actinic keratoses are rough, scaly lesions in chronically ultraviolet-exposed areas which can progress to SCC. Most SCCs arise from actinic keratoses, and various progression rates have been reported. These lesions often occur in multiples and are generally associated with alteration of surrounding skin (field) in a phenomenon known as "field cancerization". ${ }^{55,56}$ Topical 5-fluorouracil (5\%, 1\%, 0.5\%), imiquimod cream $(5 \%, 3.75 \%)$, ingenol mebutate $(0.05 \%$, $0.015 \%$ ), diclofenac sodium gel $3 \%$ with $2.5 \%$ hyaluronic gel, topical retinoids, chemical peels, lasers (ablative resurfacing with carbon dioxide) or erbium:yttrium aluminum garnet (YAG) and PDT are aimed at treating multiple lesions. 
Studies on the treatment of actinic keratoses are notoriously difficult to perform. Quantitation of actinic keratoses before and after treatment is hindered by the fact that actinic keratoses can appear and disappear spontaneously. The literature on PDT for actinic keratoses is daunting, but convincingly, ALA-PDT is an effective treatment for actinic keratoses, with an excellent cosmetic outcome, especially compared with 5 -fluorouracil and cryotherapy. ${ }^{57}$ One recent meta-analysis, which included 32 publications, found that ALA-PDT (blue light: relative risk [RR] 6.22, red light: RR 5.94,) or MAL-PDT (red light: RR 4.46,) was superior to placebo-PDT for treatment of individual lesions. Based on participant-observed complete clearance in eight interventions, efficacy from most effective to least effective was 5 -fluorouracil $>$ ALA-PDT $\sim$ imiquimod $\sim$ ingenol mebutate $\sim$ MAL-PDT $>$ cryotherapy $>$ diclofenac $>$ placebo. ${ }^{58}$

ALA-PDT with blue light is the standard for treatment of actinic keratosis, but multiple protocols exist. At our institution, ALA is applied for a one-hour incubation under occlusion prior to blue light exposure $\left(10 \mathrm{~J} / \mathrm{cm}^{2}\right)$. The use of a 5-ALA self-adhesive patch may eliminate discrepancies in ALA application. Red light has also been used for the treatment of actinic keratoses. One randomized controlled study found that complete clearance of actinic keratoses 8 weeks after treatment occurred with 4-hour incubation of the selfadhesive ALA patch ( $86 \%$ of actinic keratosis lesions) and red light therapy. Shorter incubation times at 2 hours (73\%), one hour $(72 \%)$, and half an hour (51\%) proved to be subpar. ${ }^{59}$ In one Phase III study, the 5-ALA patch-PDT without crust removal proved superior ( $82 \%$ and $89 \%$ ) to placebo-PDT $(19 \%$ and $29 \%, P<0.001)$ and cryosurgery $(77 \%)$ in improvement of actinic keratosis lesions on the scalp. ${ }^{60}$

Use of PDT has evolved from its application as monotherapy to an adjunct with other treatments. The value of sequential treatment with MAL-PDT and imiquimod was investigated in a randomized trial $(\mathrm{n}=105)$. Better response rates were seen for combination treatment than for either monotherapy; however, the difference in response was statistically significant only for the comparison between combination therapy and MAL-PDT monotherapy. ${ }^{61}$

\section{Squamous cell carcinoma}

Management of SCC is categorized by metastatic potential, ie, low-risk cutaneous SCC or high-risk (aggressive) cutaneous SCC, where surgical excision is the gold standard for the latter. Current therapies for SCC include surgical excision (Mohs surgery), cryotherapy, electrosurgery, topical treatments (5-fluorouracil and imiquimod), radiation therapy, and PDT. PDT is only recommended for treatment of SCC in situ, and not for the treatment of invasive SCC., ${ }^{5,62}$

PDT demonstrated superior efficacy and less scarring in the treatment of SCC in situ when compared with cryotherapy or 5 -fluorouracil in a Cochrane review $(n=363) .{ }^{63} \mathrm{In}$ particular, ALA-PDT appeared to have greater efficacy than 5-fluorouracil but MAL-PDT was not demonstrated to be superior over 5-fluorouracil. Also, there was no difference in recurrence rates at 12 months with either MAL-PDT or ALA-PDT when compared with 5-fluorouracil. ${ }^{64}$ There are no randomized controlled trials directly comparing treatment with ALA-PDT versus MAL-PDT. The efficacy of PDT for SCC in situ was illustrated by a trial in which 225 patients were randomly assigned to two treatments of MAL-PDT $(160 \mathrm{mg} / \mathrm{g})$ with red light $\left(570-670 \mathrm{~nm}, 75 \mathrm{~J} / \mathrm{cm}^{2}\right)$, PDT using a placebo, or conventional treatment (either cryotherapy or topical 5-fluorouracil). The lesion complete response rate at 12 months showed that MAL-PDT was superior to cryotherapy ( $80 \%$ versus $67 \%$; odds ratio 1.77 ) and also better than 5-fluorouracil ( $80 \%$ versus $69 \%$; odds ratio 1.64 ). Cosmesis at follow-up was excellent in $94 \%$ of patients treated with MAL-PDT versus $66 \%$ with cryotherapy and $76 \%$ with 5 -fluorouracil. However, lesion recurrence rates at 12 months were similar with MAL-PDT, cryotherapy, and topical 5-fluorouracil $\left(15 \%, 21 \%\right.$, and $17 \%$, respectively). ${ }^{65}$ There was also no significant difference in efficacy between MAL-PDT and 5-fluorouracil in the treatment of SCC in situ in immunosuppressed individuals. ${ }^{66}$

Several studies have looked at varying light sources. An observational study ( $\mathrm{n}=53$ ), using MAL-PDT, occlusion for 3 hours, and red light ( $630 \mathrm{~nm}, 38 \mathrm{~J} / \mathrm{cm}^{2}, 7.5$ minutes) demonstrated that $76 \%$ of the lesions achieved a complete response after two sessions with a medium follow-up of 16.6 months. ${ }^{62}$ There appears to be no superiority of ALAPDT with two-fold illumination (light treated at 4 and 6 hours with 20 and $80 \mathrm{~J} / \mathrm{cm}^{2}$ ) versus single illumination (light treated at 4 hours with $\left.75 \mathrm{~J} / \mathrm{cm}^{2}\right) \cdot{ }^{67,68}$ There was also no statistically significant difference between ALA-PDT with red light or green light regarding clearance of lesions, but there were significantly fewer recurrences at 12 months of lesions treated with red light.

In summary, PDT can be considered for treatment of SCC and SCC in situ when there are multiple lesions, in an area where multiple surgeries would result in morbidity (for example, the lower extremities), or when lesions are known to be noninvasive. For optimal treatment, red light should be utilized. MAL-PDT achieves better penetration and has been shown to be more effective than ALA-PDT. 
Multiple treatments can also increase efficacy. PDT represents an attractive option for superficial SCC given its improved cosmetic profile and similar recurrence rate when compared with cryotherapy or 5-fluorouracil. However, due to the metastatic potential and reduced efficacy rates, PDT cannot be recommended for invasive SCC.

\section{Basal cell carcinoma}

Current treatment for BCC includes Mohs micrographic surgery, excisional surgery, curettage and electrodessication, radiation, cryotherapy, PDT, laser therapy, topical treatments (imiquimod and 5-fluorouracil), and vismodegib (Erivedge ${ }^{\circledR}$, Roche Pharmaceuticals, Basel, Switzerland). Generally, PDT is recommended as a treatment option for superficial and thin nodular BCC (thickness $<2 \mathrm{~mm}$ ). However, some investigators accept $2-3 \mathrm{~mm}$ thick BCC for PDT when combined with pretreatment of lesion curettage. Preparation of the lesion prior to treatment is common, and more important for nodular BCC. Superficial debridement in a manner insufficient to cause pain is a common practice; some clinicians perform this weeks or hours in advance. One study showed a complete response, with histologic confirmation in 22 of 24 lesions (92\%) treated with PDT and prior debridement. ${ }^{69,70}$

\section{ALA-PDT treatment of BCC}

A 10-year longitudinal study that reviewed clinical and histopathologic examination of 60 lesions found that the complete response rate for primary lesions after superficial curettage was $78 \%$, with $63 \%$ after one session and $90 \%$ after two sessions. This study used ALA-PDT with halogen light (light intensity $150-230 \mathrm{~mW} / \mathrm{cm}^{2}$ ). The cosmetic outcome was rated as good or excellent in over $91 \%$ of the evaluated cases. ${ }^{71}$ Another study $(n=94)$ compared the complete response rate (mean follow-up 25 months) for superficial BCC in patients who received ALA-PDT (31/31, 100\%) versus surgery $(28 / 29,96.55 \%)$. Patients with nodular BCC had better response rates with surgery $(16 / 17,94.12 \% ; P=0.88)$ than those treated with ALA-PDT $(15 / 17,88.24 \%) .{ }^{72}$

Blue light PDT alone for $\mathrm{BCC}$ is controversial because lesions with a vertical growth greater than $2 \mathrm{~mm}$ have not been studied extensively. Clinicians should use ALA-PDT with caution for treatment of BCC, especially nodular BCC, because ALA-PDT did not seem to be an effective option for treatment of nodular BCC in one randomized controlled trial ( $\mathrm{n}=173$ ) with 3-year follow-up; recurrence rates for surgical excision $(2.3 \%)$ were substantially less compared with PDT (30.3\%). ${ }^{73}$ However, combined therapy of ALAPDT and 5\% imiquimod has been suggested to achieve a
$15 \%$ improvement in complete remission of nodular BCC compared with ALA-PDT alone. ${ }^{74}$

\section{MAL-PDT in treatment of BCC}

One noninferiority trial reported no significant difference between MAL-PDT and cryotherapy in the treatment of superficial BCC. ${ }^{75}$ Another trial showed that MAL-PDT was not inferior to surgery for treatment of nodular BCC at 3-month and 24-month follow-up. ${ }^{76}$ One French group confirmed that, at 3 months, the treatment difference (cryotherapy versus MAL-PDT) was $-2.2 \%(P=0.49)$. At 5 years, the overall lesion recurrence rate was $22 \%$ with MAL-PDT and $20 \%$ with cryotherapy. ${ }^{77}$ Szeimies et al determined that, at 3 months, the mean lesion count reduction was $92.2 \%$ for MAL-PDT versus $99.2 \%$ for surgery but this difference did not achieve statistical significance. Significantly, at 12 months, however, 9.3\% of lesions (11 of 118) recurred in the MAL-PDT group versus none in the surgery group (0 of 117). ${ }^{77}$ Although MAL-PDT is noninferior to cryotherapy and surgery, the cosmetic advantage associated with MAL-PDT is of great interest for low-risk superficial $\mathrm{BCC}$, because lesions are often multiple, typically affecting skin sites predisposed to dystrophic scarring (such as the trunk). ${ }^{78-80}$

In randomized trials comparing different treatment modalities for BCC, a recent study demonstrated increased efficacy of imiquimod over MAL-PDT (83.4\% versus $72.8 \%$ ) at 12-month follow-up. This again argues for the advantage of using combination therapies with PDT, namely adding on imiquimod after treatment. ${ }^{81}$

A consensus group in Canada and Europe analyzed nine studies and report that use of MAL-PDT can be considered as a safe and effective treatment for BCC in patients with Gorlin syndrome, the efficacy being proportionate to the thickness of the lesion. ${ }^{82}$ PDT has been observed to have chemopreventive effects in patients with Gorlin syndrome. ${ }^{83,84}$

\section{Cutaneous T cell lymphoma}

PDT has been widely used in the treatment of mycosis fungoides, an indolent subtype of cutaneous T cell lymphoma. A few studies and various case reports have reported complete or partial responses in the treatment of mycosis fungoides. Most of these report efficacy of MAL-PDT and ALA-PDT in the treatment of plaque-type (stage I) mycosis fungoides, but decreased efficacy against tumor-type (stage II) mycosis fungoides, and there has been a single report of erosive mycosis fungoides on the face treated successfully with ALA-PDT using red light. ${ }^{70,85-89}$ As is 
true for other skin tumors, PDT is less effective in deep or tumor-stage lesions. One prospective study $(n=29)$ reported an objective response in $75 \%$ of plaque or patchy lesions after monthly treatments for 6 months. ${ }^{90}$ However, a recent study observed two of five patients who appeared to have had a complete response initially, but relapsed at follow-

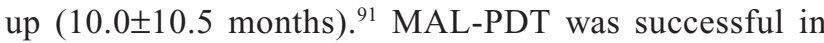
treatment-refractory mycosis fungoides (four patients with complete remission and one with partial remission). ${ }^{92}$ In conclusion, several consecutive treatments of PDT can be considered as an adjunct for treatment of mycosis fungoides, particularly for patch and plaque-stage mycosis fungoides, with good cosmetic results in sensitive skin areas.

\section{Other tumors}

PDT has also been reported in the treatment of Kaposi's sarcoma, extramammary Paget's disease, and cutaneous B cell lymphoma. ${ }^{93}$ Other proliferative disorders, such as vascular malformations, have also been treated with impressive results, likely due to the antiangiogenic effects of PDT. ${ }^{94}$

\section{PDT in inflammatory diseases Acne vulgaris}

The most common dermatologic disorder, acne vulgaris, is thought to be primarily caused by the obstruction of sebaceous glands, leading to proliferation of bacteria, mainly Propionibacterium acnes. P. acnes naturally produces porphyrins (protoporphyrin IX and coproporphyrin III), so light sources alone (blue light $>$ red light) can have a direct therapeutic photodynamic effect..$^{95}$ It is hypothesized that once applied to the skin, ALA and MAL are preferentially taken up by the pilosebaceous unit and augment the response to light therapy. The available treatments for acne currently include salicylic acid, topical retinoids, benzoyl peroxide, sulfur, alpha hydroxy acids, and various light therapies. ${ }^{96,97}$

ALA-PDT and MAL-PDT with a light-emitting diode are commonly used as off-label treatments for acne. In general, inflammatory lesions respond well to PDT, whereas comedonal/noninflammatory lesions tend to show no significant change (Table 1). The literature has focused primarily on MAL-PDT followed by red light because targeting of the sebaceous glands is optimized with this regimen. In practice, however, this treatment tends to be painful, with increased edema and milium formation. It should be noted that a 180-minute incubation time maximizes production of porphyrin in the sebaceous glands and leads to longer remission of acne (Figure 3). In a split-face study, there was no significant difference in efficacy between ALA-PDT plus red light $\left(34 \mathrm{~J} / \mathrm{cm}^{2}\right)$ and MAL-PDT plus red light $\left(34 \mathrm{~J} / \mathrm{cm}^{2}\right)$ with 3 -hour incubation times. ${ }^{98}$ Nonetheless, regimens using short incubation times (30-60 minutes) followed by blue light and/or IPL persist because they tend to be well tolerated. In these cases, frequent treatments are recommended. Such regimens have an advantage in Fitzpatrick skin types IV-VI because post-inflammatory hyperpigmentation is reduced. There may even be a role for ALA-PDT followed by IPL in the reduction of comedonal acne.

\section{ALA-PDT in acne}

The efficacy of PDT in acne was first described in a study of 22 patients, where $20 \%$ ALA was applied topically to the back with 3-hour occlusion followed by red light irradiation. This regimen was shown to reduce inflammatory acne lesions after multiple treatments (four treatments at one-week intervals) when compared with the other treatment groups (ALA alone, red light alone, untreated control) and compared with single PDT treatment in the respective study groups. After application of ALA, immunofluorescence revealed accumulation of porphyrin in areas of acne. Improvement initially was observed at 3 weeks following treatment, and was marked histologically by atrophic sebaceous glands, a granulomatous reaction, obliterated follicles, and perifollicular fibrosis. By the end of the study, there was complete destruction or a $45 \%$ decrease in sebaceous gland size. In this particular study, red light alone did not produce a therapeutic effect. ${ }^{99}$ Other small studies have also confirmed that interval treatment of ALA with varying occlusion times (3 and 4 hours) followed by red light is a highly effective treatment for acne (Table 1). ${ }^{99-102}$

The mechanism of ALA-PDT is thought to be due to selective destruction of the sebaceous unit after uptake of the photosensitizer, so the longest wavelengths capable of activating porphyrins (red light, $635 \mathrm{~nm}$ ) have been utilized to target the sebaceous glands in the dermis. Most studies have focused on ALA with red light, but a few studies have also suggested that blue light PDT has increased efficacy compared with blue light alone in the treatment of acne. ${ }^{103}$ Nonetheless, in vitro studies comparing ALA followed by blue light $(415 \mathrm{~nm})$ or red light $(635 \mathrm{~nm})$ and examining the bactericidal effects on $P$. acnes, found that red light phototherapy was less effective for the eradication of $P$. acnes than blue light phototherapy with and without ALA. ${ }^{104}$ Therefore, there may still be a role for combined blue and red light activation of ALA in the treatment of acne. 
Table I Comparative studies on PDT light sources in treatment of acne

\begin{tabular}{|c|c|c|c|c|}
\hline Reference & $\mathbf{N}$ & $\begin{array}{l}\text { Type of trial; study } \\
\text { population/type }\end{array}$ & $\begin{array}{l}\text { Light source (dose); } \\
\text { incubation time }\end{array}$ & $\begin{array}{l}\text { Session number } \\
\text { (interval); follow-up }\end{array}$ \\
\hline $\begin{array}{l}\text { Pinto } \\
\text { et al }\left.\right|^{176} \\
2013\end{array}$ & 36 & $\begin{array}{l}\text { Prospective, controlled, } \\
\text { investigator-blinded; mild- } \\
\text { to-moderate acne }\end{array}$ & $\begin{array}{l}\text { MAL-PDT versus red } \\
\text { light (average wavelength } \\
635 \mathrm{~nm} \text {, light dose } 37 \mathrm{~J} / \mathrm{cm}^{2} \text {, } \\
\text { fluence rate approximately } \\
70 \mathrm{~mW} / \mathrm{cm}^{2} \text { ) alone; } \\
90 \text { minutes }\end{array}$ & $\begin{array}{l}2 \times(2 \text { weeks }) \\
10 \text { weeks }\end{array}$ \\
\hline
\end{tabular}

$\begin{array}{ll}\text { Hong et } \text { al }^{49} \quad 20 & \text { Split-face, Fitzpatrick } \\ 2013 & \text { skin phototypes IV-V }\end{array}$

2013 $\begin{array}{ll}\text { MAL-PDT + red light } & 3 \times(2 \text { weeks }) \text {; } \\ \left(22 \mathrm{~J} / \mathrm{cm}^{2} \text { and fluence rate }\right. & 4 \text { weeks } \\ \left.\text { was } 34 \mathrm{~mW} / \mathrm{cm}^{2}\right) \text { versus } & \\ \text { IPL }(530-750 \mathrm{~nm} \text {; fluence } & \\ \left.8-10 \mathrm{~J} / \mathrm{cm}^{2}\right) & \end{array}$

IL-ALA versus IPL $(560 \mathrm{~nm}, \quad 3 \times($ I week); fluence $26 \mathrm{~J} / \mathrm{cm}^{2}$, $15 \mathrm{msec} \quad$ I month

Boucher $^{180}$ et al $^{177}$

2012

Haedersdal

et $\mathrm{al}^{178}$

2008

Sadick $^{179}$

2010

Barolet and

2010

Yeung

et al $^{181}$

2007

30 Controlled; nodulocystic and inflammatory acne vulgaris on face and back

12 Split-face, randomized, controlled; Fitzpatrick skin type I-III, inflammatory lesions

20 Split-face, randomized; moderate-to-severe acne

10 Split-face/back; randomized, controlled, investigator-blinded

23 Split-face, randomized, single-blind; Fitzpatrick skin phototypes IV or V, moderate acne

20 Split-face; moderateto-severe acne

et al ${ }^{103}$

2007

\begin{tabular}{|c|c|c|}
\hline $\begin{array}{l}\text { Rojanamatin } \\
\text { and }\end{array}$ & 14 & Split-face \\
\hline \multicolumn{3}{|c|}{ Choawawanich ${ }^{182}$} \\
\hline 2006 & & \\
\hline $\begin{array}{l}\text { Hörfelt } \\
\text { et al }{ }^{105}\end{array}$ & 30 & $\begin{array}{l}\text { Split-face; blinded, } \\
\text { prospective, randomized, }\end{array}$ \\
\hline 2006 & & $\begin{array}{l}\text { placebo-controlled; } \\
\text { moderate-to-severe acne }\end{array}$ \\
\hline $\begin{array}{l}\text { Wiegell and } \\
\text { Wulf }\end{array}$ & 36 & $\begin{array}{l}\text { Randomized, controlled, } \\
\text { investigator-blinded }\end{array}$ \\
\hline \multicolumn{3}{|l|}{2006} \\
\hline $\begin{array}{l}\text { Wiegell and } \\
\text { Wulf }\end{array}$ & 15 & $\begin{array}{l}\text { Split-face; randomized, } \\
\text { controlled, investigator- }\end{array}$ \\
\hline 2006 & & blinded \\
\hline $\begin{array}{l}\text { Santos } \\
\text { et al }{ }^{183}\end{array}$ & 13 & $\begin{array}{l}\text { Split-face; I and NI } \\
\text { lesions }\end{array}$ \\
\hline 2005 & & \\
\hline
\end{tabular}

pulse, 2-3 passes) alone;

30 minutes

MAL-LPDL versus LPDL $3 \times(2$ weeks);

$\left(595 \mathrm{~nm}, 7.5 \mathrm{~J} / \mathrm{cm}^{2}, 10 \mathrm{msec}, \quad 12\right.$ weeks

2 passes); 3 hours

ALA-KTP versus KTP

$(532 \mathrm{~nm})$ only

Pretreatment with infrared Once; 4 weeks

LED $(970 \mathrm{~nm})$ and ALA-

PDT + LED (630 nm)

versus LED $(630 \mathrm{~nm})$ only

16\% MAL-IPL versus IPL $\quad 4 \times$ (3 weeks); (530-750 nm, double pulses, 12 weeks $2.5 \mathrm{msec}$ ) only versus placebo; 30 minutes

10\% ALA-PDT versus blue $\quad 4 \times$ (I week); light $\left(415 \mathrm{~nm}, 40 \mathrm{~mW} / \mathrm{cm}^{2}, \quad 16\right.$ weeks $\left.48 \mathrm{~J} / \mathrm{cm}^{2}\right)$; I hour

$20 \%$ ALA-IPL versus IPL $\quad 3 \times(3-4$ weeks $)$; (560-590 nm, 25-30 J/cm², 12 weeks double pulse) only;

30 minutes

$16.8 \%$ MAL-PDT versus $\quad 2 \times(2$ weeks $)$;

placebo; 3 hours 10 weeks

$16.8 \%$ MAL-PDT versus $\quad 2 \times(2$ weeks $)$;

placebo; 3 hours 12 weeks

$20 \%$ ALA-PDT versus $16.8 \%$ Once; 12 weeks

MAL-PDT; both with red

light $\left(630 \mathrm{~nm}, 37 \mathrm{~mW} / \mathrm{cm}^{2}\right.$, $\left.34 \mathrm{~J} / \mathrm{cm}^{2}\right) ; 3$ hours

$20 \%$ ALA-IPL versus IPL $\quad 2 \times(2$ weeks);

$\left(560 \mathrm{~nm}, 26 \mathrm{~J} / \mathrm{cm}^{2}\right.$, double 8 weeks pulse) alone; 3 hours
Results

MAL-PDT > red light alone: greater and more rapid clinical and histologic responses in MAL-PDT than red light only group. Histologically, decreased amount of sebocytes, lipids, and atrophic sebaceous glands. Week I0, MAL-PDT (100\%), red light only (77.7\%) achieved successful treatment.

MAL-PDT + red light produced a more rapid response in I and $\mathrm{NI}$ lesions than IPL, but both had satisfactory results. Decrease fluence for Fitzpatrick skin type IV-V given increased risk of postinflammatory hyperpigmentation. IL-ALA > IPL alone: inflammatory lesion count was less in IL-ALA. Recurrence after I month: $16.67 \%$ IL-ALA, I00\% IPL only.

MAL-LPDL > LPDL alone but not powered to study efficacy of LPDL alone; median reduction of inflammatory lesions: 80\% MAL-LPDL, 67\% LPDL. Improvement in acne: 52\% ALA-KTP, $32 \%$ KTP.

Inflammatory lesion reduction: $73 \%$ IR + ALA-PDT + LED, 38\% LED. Improvement in clinical severity and reduction of $\mathrm{NI}$ lesions with IR + ALA-PDT $(P=0.027$ and $P=0.037$, respectively).

Control > MAL-IPL > IPL only: reduction of inflammatory lesions: $88 \%$ control, $65 \%$ MAL-IPL, 23\% IPL (not significant). Reduction of noninflammatory lesions: $38 \%$ MAL-IPL $(P=0.05)$, 44\% IPL ( $P=0.01)$; $15 \%$ increase in control group $(P=0.36)$. Reduction of inflammatory lesions: $71.1 \%$ ALA-PDT, $56.7 \%$ blue light alone (not significant). No significant difference in lipid level.

Reduced lesion count $87.7 \%$ ALA-IPL, $66.8 \%$ IPL only (difference not significant).

MAL-PDT > placebo: inflammatory lesion reduction: 54\% MAL-PDT, 20\% placebo. Difference in NI lesions not significant.

MAL-PDT > placebo: inflammatory lesion reduction: $68 \%$ MAL-PDT, $0 \%$ control. No improvement in $\mathrm{NI}$ lesions. A $59 \%$ decrease in inflammatory lesions but no significant difference between MAL and ALA.

ALA-IPL > IPL alone: ALA-IPL visible improvement (76.9\%), IPL alone returned to baseline of facial acne. 
Table I (Continued)

\begin{tabular}{|c|c|c|c|c|c|}
\hline Reference & $\mathbf{N}$ & $\begin{array}{l}\text { Type of trial; study } \\
\text { population/type }\end{array}$ & $\begin{array}{l}\text { Light source (dose); } \\
\text { incubation time }\end{array}$ & $\begin{array}{l}\text { Session number } \\
\text { (interval); follow-up }\end{array}$ & Results \\
\hline $\begin{array}{l}\text { Hong and } \\
\text { Lee }^{184} \\
2005\end{array}$ & 8 & Split-face & $\begin{array}{l}20 \% \text { ALA-PDT + red light } \\
\left(630 \pm 63 \mathrm{~nm}, 30 \mathrm{~mW} / \mathrm{cm}^{2},\right. \\
\left.18 \mathrm{~J} / \mathrm{cm}^{2}\right) \text { versus placebo; } \\
4 \text { hours }\end{array}$ & Once; 6 months & $\begin{array}{l}\text { Inflammatory lesion reduction: } 41.9 \% \\
\text { ALA-PDT, I5.4\% placebo. Reductions } \\
\text { in noninflammatory lesions were not } \\
\text { statistically significant. }\end{array}$ \\
\hline $\begin{array}{l}\text { Pollock } \\
\text { et al } \\
2004\end{array}$ & 10 & $\begin{array}{l}\text { Controlled; mild-to- } \\
\text { moderate acne on the } \\
\text { back }\end{array}$ & $\begin{array}{l}20 \% \text { ALA-PDT versus red } \\
\text { light }\left(635 \mathrm{~nm}, 25 \mathrm{~mW} / \mathrm{cm}^{2} \text {, }\right. \\
\left.10 \mathrm{~J} / \mathrm{cm}^{2}\right) ; 3 \text { hours }\end{array}$ & $3 \times(I$ week $) ; 3$ weeks & $\begin{array}{l}\text { Reduction in inflammatory acne lesions } \\
\text { after second treatment at ALA-PDT site } \\
\text { but not other sites or treatments. }\end{array}$ \\
\hline $\begin{array}{l}\text { Goldman } \\
\text { and Boyce } \\
2003\end{array}$ & 22 & $\begin{array}{l}\text { Controlled; mild-to- } \\
\text { moderate acne }\end{array}$ & $\begin{array}{l}20 \% \text { ALA-PDT versus } \\
\text { blue light }(4 \mathrm{I} 7 \pm 5 \mathrm{~nm} \text {, } \\
\left.10 \mathrm{~mW} / \mathrm{cm}^{2}, 3.6 \mathrm{~J} / \mathrm{cm}^{2}\right) \text { only; } \\
15 \text { minutes }\end{array}$ & $2 \times ; 2$ weeks & $\begin{array}{l}\text { Inflammatory lesion reduction: } 68 \% \text { ALA- } \\
\text { PDT, } 40 \% \text { blue light. }\end{array}$ \\
\hline $\begin{array}{l}\text { Hongcharu } \\
\text { et } \text { al }^{99} \\
2000\end{array}$ & 22 & $\begin{array}{l}\text { Randomized; mild-to- } \\
\text { moderate inflammatory } \\
\text { acne }\end{array}$ & $\begin{array}{l}20 \% \text { ALA-PDT + red light } \\
\text { versus light alone } \\
\left(550-570 \mathrm{~nm}, 150 \mathrm{~J} / \mathrm{cm}^{2}\right) \\
\text { versus placebo; } 3 \text { hours }\end{array}$ & $\begin{array}{l}\text { Randomized to } \mathrm{I} \times \\
\text { versus } 4 \times(\mathrm{I} \text { week }) \\
20 \text { weeks }\end{array}$ & $\begin{array}{l}\text { ALA-PDT } 4 \text { sessions }>\text { ALA-PDT } \\
\text { I session }>\text { red light alone }>\text { placebo. } \\
\text { Histology: sebaceous glands smaller after } \\
\text { ALA-PDT. }\end{array}$ \\
\hline $\begin{array}{l}\text { Papageorgiu } \\
\text { et al }{ }^{186} 2000\end{array}$ & 107 & $\begin{array}{l}\text { Randomized; mild-to- } \\
\text { moderate acne }\end{array}$ & $\begin{array}{l}\text { Blue light ( } 4 \text { I } 5 \mathrm{~nm}) \text { versus } \\
\text { mixed blue and red light } \\
(415 \mathrm{~nm} \text { and } 660 \mathrm{~nm}) \text { versus } \\
5 \% \text { benzoyl peroxide versus } \\
\text { cool white light; } 15 \text { minutes }\end{array}$ & $\begin{array}{l}\text { Daily } \times(12 \text { weeks }) \\
8 \text { weeks }\end{array}$ & $\begin{array}{l}\text { Mixed blue-red > other treatments. } \\
\text { At } 8 \text { weeks: } 76 \% \text { improvement in } \\
\text { inflammatory lesions with blue-red light, } \\
\text { greater than blue light and benzoyl } \\
\text { peroxide (\% not reported); } 58 \% \\
\text { improvement in comedones with blue- } \\
\text { red light (not significant). }\end{array}$ \\
\hline
\end{tabular}

Abbreviations: I, inflammatory; NI, noninflammatory; IL, intralesional; PDT, photodynamic therapy; ALA, aminolevulinic acid; MAL, methyl aminolevulinate; IPL, intense pulsed light; LPDL, long-pulsed dye laser; LED, light-emitting diode; IR, infrared; KTP, potassium titanyl phosphate.

\section{MAL-PDT in acne}

MAL-PDT followed by red light has been well documented in the literature. One split-face study $(n=30)$ used MAL with a 3-hour occlusion followed by red light, and showed a statistically significant median reduction in inflammatory lesion count at 12 weeks (54\%) when compared with placebo $\left(20 \%\right.$; 95\% confidence interval 8\%-50\%). ${ }^{105}$ Another study $(n=21)$ compared the use of MAL-PDT with the same regimen (3-hour occlusion and red light) versus placebo, and reported a median $68 \%$ reduction $(P=0.0023)$ of inflammatory lesions upon clinical examination at 12 weeks post treatment. However, there was no significant difference in noninflammatory lesions. ${ }^{106}$ Interestingly, one study $(\mathrm{n}=16)$ concluded that a diluted concentration of $4 \%$ MAL resulted in similar efficacy (average 66\% reduction for inflammatory lesions) with reduced side effects (most commonly, pain), and this formulation may be a more cost-effective strategy. ${ }^{107}$

\section{Other photosensitizers}

Other topical photosensitizers, which have been studied less extensively, include indocyanine green (or methylene blue) and indole-3-acetic acid. ${ }^{32,33,108-113}$ Indole-3-acetic acid in particular may have an important role in clinical practice, primarily because patients receiving indole-3-acetic acid for acne experience less pain. It also has promising practical aspects, requiring shorter incubation times whilst producing equivalent efficacy (Table 2).

\section{Rosacea}

Rosacea, sometimes termed "adult acne", although similar in appearance to acne, has a different pathophysiology. Common current treatments include topical metronidazole, topical azelaic acid, oral tetracyclines, and most recently, topical alpha-2 adrenergic agonists. Recent evidence suggests that rosacea may represent an altered immune reactivity to the microbes of the skin. ${ }^{114}$

The use of ALA-PDT in rosacea is primarily anecdotal, with few randomized controlled studies published thus far. MAL-PDT with red light has been shown to improve the appearance of rosacea, in particular papulopustular lesions when compared with the erythematotelangiectatic types. ${ }^{115}$ One small, prospective study $(n=4)$ demonstrated increased efficacy using PDT with long-pulsed dye laser (LPDL) versus LPDL alone in the treatment of inflammatory papulopustular rosacea. ${ }^{116}$ However, in a controlled study, the long-term benefit of MAL-PDT with LPDL compared with LPDL alone demonstrated no difference. ${ }^{116}$ This study does not rule out the possibility that other light sources may work in combination with ALA to treat rosacea effectively. 

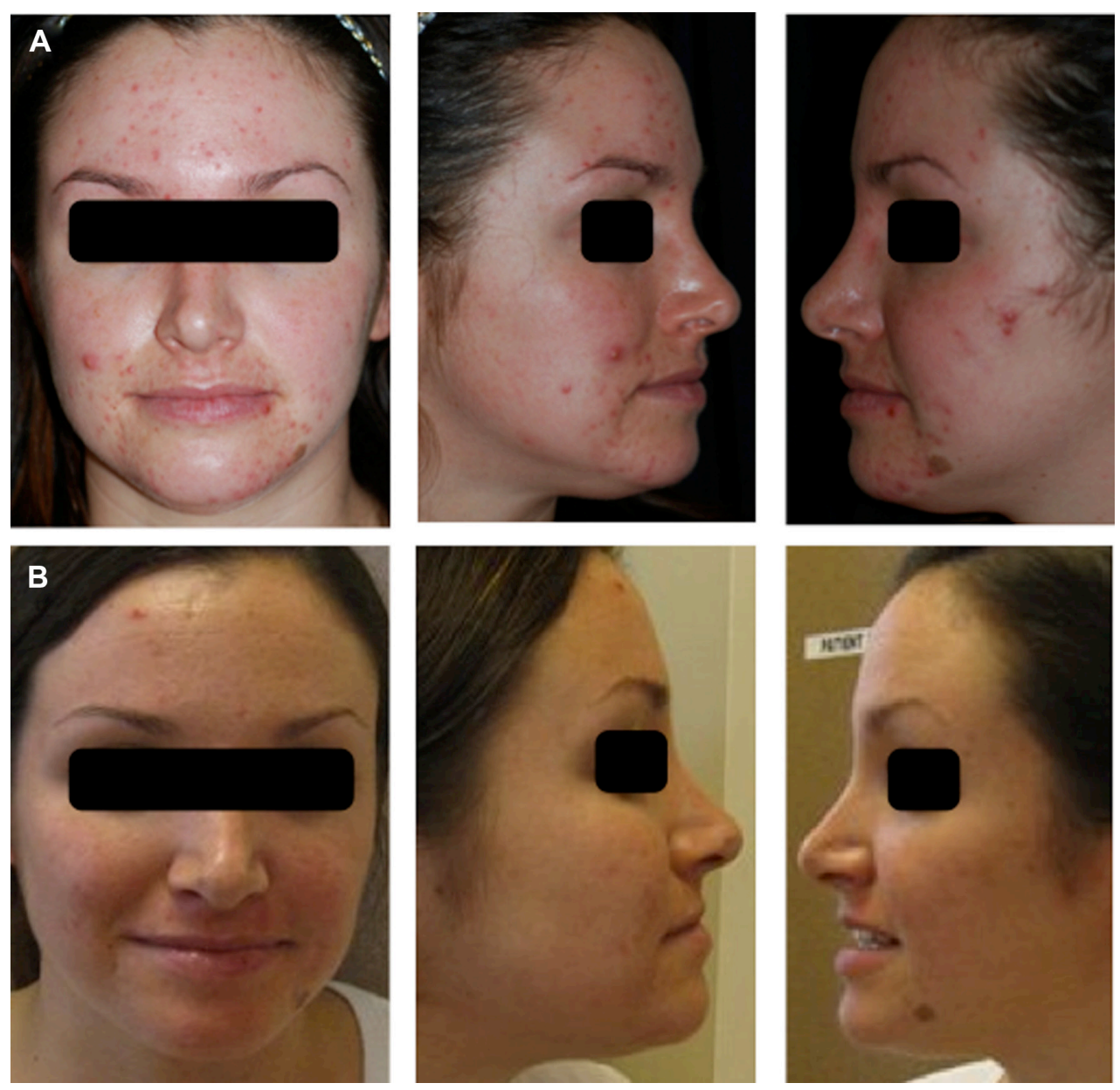

Figure 3 Improvement in a 27-year-old woman with inflammatory papules on the face. (A) Before treatment (top row). (B) Three-month follow-up after one treatment of MAL-PDT with red light, ie, $200 \mathrm{~J} / \mathrm{cm}^{2}$, and 180 -minute incubation under occlusion (bottom row).

Abbreviations: MAL, methyl aminolevulinate; PDT, photodynamic therapy.

Table 2 Use of indole-3-acetic acid and photodynamic therapy in treatment of acne

\begin{tabular}{|c|c|c|c|c|c|}
\hline Reference & Indication & $\mathbf{n}$ & Type of trial & $\begin{array}{l}\text { Treatment regimen; } \\
\text { session number (interval) }\end{array}$ & Results \\
\hline $\begin{array}{l}\text { Kwon } \\
\text { et al }{ }^{187} 2013\end{array}$ & $\begin{array}{l}\text { Seborrheic } \\
\text { dermatitis }\end{array}$ & 23 & $\begin{array}{l}\text { Prospective, single- } \\
\text { blind }\end{array}$ & $\begin{array}{l}\text { IAA-PDT with green light } \\
(520 \mathrm{~nm}) ; 2 \times(\text { I week })\end{array}$ & $\begin{array}{l}\text { Sebum excretion significantly reduced at } \\
\text { week } 2 \text { until week } 6 \text {. }\end{array}$ \\
\hline $\begin{array}{l}\text { Huh } \\
\text { et al }{ }^{188} 2012\end{array}$ & Acne vulgaris & 25 & Prospective & $\begin{array}{l}\text { IAA-PDT I } 5 \text { minutes of } \\
\text { occlusion, and green light for } \\
\text { I5 minutes; } 5 \times(\text { I week })\end{array}$ & $\begin{array}{l}\text { Inflammatory and noninflammatory acne } \\
\text { lesions were significantly decreased; sebum } \\
\text { secretion and erythema were reduced; } \\
\text { histopathologic reduction of inflammation. }\end{array}$ \\
\hline $\begin{array}{l}\text { Jang } \\
\text { et } \mathrm{al}^{32} 201 \mathrm{I}\end{array}$ & Acne vulgaris & 34 & $\begin{array}{l}\text { Prospective, single- } \\
\text { blind, split-face }\end{array}$ & $\begin{array}{l}\text { IAA-PDT with green light } \\
(520 \mathrm{~nm}) \text { on half of the face } \\
\text { and ICG with near-infrared } \\
\text { radiation }(805 \mathrm{~nm}) \text { on the } \\
\text { other half; } 5 \times(\mathrm{I} \text { week) }\end{array}$ & $\begin{array}{l}\text { Inflammatory }>\text { noninflammatory acne } \\
\text { lesions decreased; sebum secretion } \\
\text { decreased; up to } 3 \text { months of follow-up for } \\
\text { subjective satisfaction score; no statistically } \\
\text { significant difference between the two } \\
\text { treatments. }\end{array}$ \\
\hline $\begin{array}{l}\mathrm{Na} \\
\text { et al }{ }^{189} 201 \mathrm{I}\end{array}$ & Acne vulgaris & 14 & $\begin{array}{l}\text { Prospective, biopsies } \\
\text { on nude mice as well }\end{array}$ & $\begin{array}{l}\text { IAA-PDT with green light } \\
(520 \mathrm{~nm}) ; 3 \times(2 \text { week })\end{array}$ & $\begin{array}{l}\text { Growth of Propionibacterium acnes and } \\
\text { Staphylococcus aureus was significantly } \\
\text { suppressed; treated skin showed } \\
\text { destruction of follicular ostia epithelium; } \\
\text { no significant difference between 4-hour } \\
\text { and 30-minute incubation; inflammatory } \\
\text { lesions and sebum secretion were reduced. }\end{array}$ \\
\hline
\end{tabular}


Microbes such as Demodex and Staphylococcus epidermidis have both been implicated in the pathogenesis of rosacea. One in vitro study demonstrates the ability of ALAPDT to decrease the biofilm of Staphylococci and another study demonstrated eradication of Demodex. ${ }^{117,118}$ In contrast, one clinical study suggested that there was no change in the bacterial flora of the skin after MAL-PDT. ${ }^{119}$

Unlike acne, the results of PDT on rosacea are inconclusive at best. In general, the papulopustular elements seem to respond as compared with the erythematotelangiectatic elements. Patients should be warned that some may experience increased erythema after the therapy.

\section{Other inflammatory disorders}

Hidradenitis suppurativa has been treated with MALPDT with excellent results, although negative studies also exist. ${ }^{120,121}$ PDT has also been reported to have an effect on morphea and actinic cheilitis. ${ }^{122}$

\section{PDT in microbial diseases Viruses}

Human papillomaviruses can manifest in a variety of ways, including as warts, cervical carcinoma, anogenital SCC, and papillomatosis. Warts are the most common entity of this virus. Treatment of warts (verrucae vulgaris, verrucae plana) includes surgical excision, cryotherapy, curettage, surgical excision, topical cytotoxic medications (5-fluorouracil, dinitrochlorobenzene), intralesional bleomycin, infrared coagulation, $\mathrm{CO}_{2}$ laser therapy, PDL, PDT, and electrosurgery. However, some lesions remain recalcitrant to therapy, and many commonly recur after successful treatment. ALA-PDT has been shown to successfully treat cutaneous warts without significant side effects and excellent cosmetic results in several studies. Reported clearance rates are as high as $88 \%$. The clearance rate seems proportionate to the size of the warts, and mean treatment time. ${ }^{123}$ ALA-PDT with white light (halogen lamp; $250 \mathrm{~W}$ Osram; delivered via slide projector) was found to be more efficacious than red or blue light and standard cryotherapy. ${ }^{124}$ One case report demonstrated the use of fractional resurfacing to aid PDL-PDT delivery in a recalcitrant plantar wart. ${ }^{125}$

Other virus-mediated lesions treated successfully with PDT have been reported. Epidermodysplasia verruciformis was successfully treated with ALA-PDT. Within 3 weeks, the lesions had completely healed without scarring after one treatment. ${ }^{126}$ Eradication of human papillomavirus in genital warts (condyloma acuminata) has been shown with use of PDT in conjunction with 5-ALA, Photolon ${ }^{\mathrm{TM}}$ (Belmedpreparaty, Minsk, Republic of Belarus), polyhe- matoporphyrin, and YAG-OPO laser irradiation or $\mathrm{CO}_{2}$ laser vaporization. ${ }^{127-133}$ Finally, there are reports of successful treatment with PDT for cases of molluscum contagiosum and herpes simplex virus. ${ }^{134,135}$ In this setting, PDT is still working primarily in an antiproliferative manner. The advantage continues to be the ability to treat a large surface area, and with minimal scarring. In terms of recurrence rates, it is unclear whether PDT or $\mathrm{CO}_{2}$ laser therapy is superior. ${ }^{133,136}$

\section{Onychomycosis}

Past clinical trials have suggested that tinea cruris, tinea pedis, and interdigital mycoses recur frequently when treated with ALA-PDT. ${ }^{137-139}$ However, more recently, one clinical trial $(n=30)$ used chemical avulsion (occlusion with urea for ten consecutive nights prior to PDT) and 20\% ALA-PDT (3-hour incubation) followed by red light therapy, and demonstrated a $43.3 \%$ cure rate at 12 -month follow-up, which dropped to $36.6 \%$ at 18 -month follow-up. ${ }^{140}$ Two other case series reported complete resolution of fungal infection with PDT. One case demonstrated successful treatment of subungual onychomycosis after occlusion with urea for 7 days followed by MAL-PDT with broadband red light $\left(37 \mathrm{~J} / \mathrm{cm}^{2}\right)$. This was repeated every 2 weeks for a total of three treatments. In this case, Trichophyton rubrum was the causative organism and previously had been demonstrated to be sensitive to PDT in vitro. Nondermatophyte molds have also been cleared with MAL-PDT and red light. ${ }^{141,142}$

Other nonhematoporphyrin-derived photosensitizers (Sylsens $B$ being the most effective) have also been shown to be efficacious in the treatment of onychomycosis. ${ }^{143,144}$ Major concerns regarding effective drug penetration through thick, hyperkeratotic ungual barriers have led to introduction of new delivery methods involving iontophoretic and ultrasound devices, which enable increased nail bed permeability. ${ }^{145,146}$ Most recently, one patient with treatment-resistant onychomycosis was successfully pretreated with a micro motor pneumatic diamond drill device and subsequent ALA-PDT with red light. ${ }^{147}$

\section{Leishmaniasis}

Cutaneous leishmaniasis is the most common form of leishmaniasis, and is transmitted by sand flies. Various case reports and series have documented successful treatment of cutaneous leishmaniasis using PDT. Studies have also shown PDT to be effective in the treatment of antibiotic-resistant cutaneous leishmaniasis, further strengthened by another study comparing the efficacy of PDT versus paromomycin or methylbenzethonium chloride. ${ }^{148-151}$ Individual cases demonstrating successful treatment using MAL-PDT include an 8-year-old Italian girl and an Austrian patient infected 
with Leishmania major. ${ }^{91,152}$ Clinicians can consider PDT as a safe and efficacious treatment option for cutaneous leishmaniasis.

\section{Other infections}

Erythrasma is the cutaneous manifestation of Corynebacterium minutissimum, characterized by heterogeneous coral-red fluorescence due to presence of endogenous porphyrins in the bacteria. PDT with red light irradiation and without an exogenous photosensitizer achieved complete clearance in $23 \%$ of lesions $(3 / 22)$ and partial clearance in $82 \%$ of lesions $(18 / 22) .{ }^{153}$ Reports of unsuccessful ALA-PDT in the treatment of Candida albicans intertrigo have been documented. ${ }^{139}$

\section{PDT in proliferative disease}

\section{Photoaging/antiaging/photorejuvenation}

Photoaging is characterized by increased skin elastosis associated with degraded collagen. Clinically, one can observe irreversible skin hyperpigmentation, ephelides, lentigines, abnormal elastic fibers, telangiectasias, sebaceous gland hyperplasia, and rhytids. ${ }^{154,155}$ Histopathologically, dilated blood vessels and increased pigment are found accumulated in the papillary dermis. ${ }^{156-160}$ Current treatments for photorejuvenation include retinoids, laser resurfacing, chemical peels, and various light therapies (Table 3). Photorejuvenation has been frequently observed in patients undergoing PDT for other disease entities, and therefore has become an area of further investigation.

\section{PDT with blue light}

ALA-PDT with blue light has been reported to improve skin elasticity, as well as skin texture, pigmentation, fine lines, and complexion. ${ }^{161-163}$ Deep wrinkling and mottled hyperpigmentation have not been reported to change following treatment.

\section{PDT with red light}

One study $(\mathrm{n}=20)$ revealed a statistically significant improvement $(P<0.05)$ after administration of MAL-PDT and red light with respect to mottled hyperpigmentation, fine lines, skin roughness, and sallowness, but no improvement of deep wrinkles, superficial angiogenesis, facial erythema, and sebaceous gland hyperplasia. To quantify epidermal and dermal changes during PDT, an analysis using high-resolution echography showed increased skin thickness, which the authors postulated to be caused by increased collagen synthesis. ${ }^{164}$ One investigator-blinded study with a 2-month follow-up revealed moderate improvement in fine lines, tactile roughness, and skin tightness, especially on the half of the face that had a 3-hour incubation with MAL compared with a one-hour incubation. In contrast with other studies, there was no change in mottled hyperpigmentation, and consistent with other reports, no improvement of telangiectasias. ${ }^{165} \mathrm{~A}$ larger clinical split-face trial $(n=94)$ demonstrated superiority in terms of improvement in global photodamage using MAL-PDT with red light versus placebo. ${ }^{166}$ Opposing studies exist, however, including one study that compared blue light versus red light and MAL-PDT. In this study, no difference in efficacy was observed in photodamaged skin. ${ }^{167}$

\section{PDT with intense pulsed light}

One retrospective split-face study $(\mathrm{n}=20)$ compared pretreatment with 5-ALA (5-ALA first treatment, IPL only for last two treatments) on one half of the patient's face versus IPL treatment alone. After three treatments, greater subjective improvement was observed in the ALA-IPL arm in terms of global photoaging, mottled pigmentation, and fine lines. ${ }^{168}$ Pretreatment with ALA did not improve observed sallowness or tactile roughness at one-month follow-up after five treatments. Following this, another split-face study $(n=13)$ reported similar results, with improved appearance of crow's feet (55\% versus $29.5 \%$ ), tactile skin roughness ( $55 \%$ versus $29.5 \%$ ), mottled hyperpigmentation (60.3\% versus $37.2 \%)$, and telangiectasias $(84.6 \%$ versus $53.8 \%$ ) in the ALA-IPL group. ${ }^{169}$ A major advantage of IPL compared with irradiation with a light-emitting diode is less time expenditure and less painful effects of heat delivery due to shorter intense exposure times. ${ }^{170}$ Clinicians should be aware that heat delivered by IPL may cause destruction of hair follicles, so it should be used with caution, especially in men with facial hair.

Mechanisms supporting PDT-induced photorejuvenation have been proposed. Studies involving punch biopsies after ALAIPL demonstrate an increase in type I collagen. Interestingly, Orringer et al used biomarkers to examine the molecular effects of ALA-PDT and PDL, and showed upregulation of Ki-67 (an immunohistochemical biomarker of keratinocyte proliferation), along with elevated levels of procollagen I and procollagen III, indicating new formation of collagen. ${ }^{159}$

\section{Other proliferative conditions}

PDT has been shown to reduce type I collagen synthesis and fibroblast activity in vitro, thus potentially having a role in the treatment of scars. ${ }^{171}$ Several groups have demonstrated improvement in the skin flexibility of hypertrophic scars using MAL-PDT. ${ }^{172,173}$ One recent study $(n=20)$ demonstrated that three treatments of MAL-PDT were effective in reducing formation of keloid scars, which were 
Table 3 Comparative studies of PDT light sources in photorejuvenation/photoaging

\begin{tabular}{|c|c|c|c|c|c|}
\hline Reference & $\mathbf{n}$ & $\begin{array}{l}\text { Type } \\
\text { of study }\end{array}$ & $\begin{array}{l}\text { Light sources (light doses); } \\
\text { incubation times }\end{array}$ & $\begin{array}{l}\text { Session number } \\
\text { (interval); follow-up }\end{array}$ & Results \\
\hline $\begin{array}{l}\text { Haddad et al }{ }^{190} \\
2011\end{array}$ & 24 & Comparative & $\begin{array}{l}20 \% \text { ALA-IPL }(20,25,40 \text {, and } \\
\left.50 \mathrm{~J} / \mathrm{cm}^{2}\right) \text { versus IPL only; } \\
2 \text { hours }\end{array}$ & Once; 8 weeks & $\begin{array}{l}\text { Photorejuvenation did not seem to } \\
\text { improve with increasing IPL fluence } \\
\text { levels. }\end{array}$ \\
\hline $\begin{array}{l}\text { Xi et al }{ }^{191} \\
2011\end{array}$ & 24 & $\begin{array}{l}\text { Split-face, } \\
\text { prospective, } \\
\text { controlled }\end{array}$ & $\begin{array}{l}5 \% \text { and } 10 \% \text { ALA, IPL }(560 \mathrm{~nm} \\
\text { or } 590 \mathrm{~nm}, 14-20 \mathrm{~J} / \mathrm{cm}^{2} \\
3.5-4 \mathrm{msec} \text {, double or triple } \\
\text { pulses); I hour }\end{array}$ & $\begin{array}{l}3 \times(4 \text { weeks }) \\
2 \text { months }\end{array}$ & $\begin{array}{l}\text { ALA-IPL > IPL: global score: } 50 \% \\
\text { ALA-IPL, I2.5\% IPL only. Fine lines: } \\
70.8 \% \text { ALA-IPL, } 33.3 \% \text { IPL only. Coarse } \\
\text { wrinkles: } 50 \% \text { ALA-IPL, I } 2.5 \% \text { IPL only. } \\
\text { No significant difference with respect to } \\
\text { mottled pigmentation and skin roughness. }\end{array}$ \\
\hline $\begin{array}{l}\text { Kosaka et al }{ }^{192} \\
2010\end{array}$ & 16 & Split-face & $\begin{array}{l}5 \% \text { ALA + IPL (500-670 nm } \\
\text { and } 870-I, 400 \mathrm{~nm}, 23-30 \mathrm{~J} / \mathrm{cm}^{2}, \\
20 \text { msec, single pulses); } 2 \text { hours }\end{array}$ & $\begin{array}{l}3 \times(4 \text { weeks }) \\
3 \text { months }\end{array}$ & $\begin{array}{l}\text { Significant improvement of signs of skin } \\
\text { aging, equal on both sides (ALA-IPL and } \\
\text { IPL alone). However, } 75 \% \text { of patients found } \\
\text { ALA-IPL more effective than IPL alone. }\end{array}$ \\
\hline $\begin{array}{l}\text { Bjerring } \\
\text { et al }{ }^{193} \\
2009\end{array}$ & 37 & $\begin{array}{l}\text { Split-face, } \\
\text { prospective, } \\
\text { randomized }\end{array}$ & $\begin{array}{l}0.5 \% \text { liposome-encapsulated } \\
\text { ALA-IPL ( } 530-750 \mathrm{~nm} \text {, } \\
\text { rejuvenation filter, } 6-7 \mathrm{~J} / \mathrm{cm}^{2} \text {, } \\
\text { double pulses of } 2.5 \mathrm{msec}) \\
\text { versus ALA-IPL }(400-720 \mathrm{~nm} \text {, } \\
\left.3.5 \mathrm{~J} / \mathrm{cm}^{2}, 30 \mathrm{msec}\right)\end{array}$ & $\begin{array}{l}3 \times(3 \text { weeks }) \\
3 \text { months }\end{array}$ & $\begin{array}{l}\text { ALA-IPL }(530-750 \mathrm{~nm}) \text { versus ALA-IPL } \\
(400-720 \mathrm{~nm}) \text { : significant reduction of } \\
\text { perioral and periorbital wrinkles on } \\
\text { both sides. Pigmentation, erythema, and } \\
\text { telangiectasias better with IPL }(530-750 \mathrm{~nm}) \text {. }\end{array}$ \\
\hline $\begin{array}{l}\text { Ruiz-Rodriquez } \\
\text { et al }{ }^{165} \\
2008\end{array}$ & 10 & $\begin{array}{l}\text { Split-face, } \\
\text { randomized, } \\
\text { prospective }\end{array}$ & $\begin{array}{l}\text { I6\% MAL-PDT + red light; } \\
\text { I hour versus } 3 \text { hours }\end{array}$ & $3 \times ; 2$ months & $\begin{array}{l}\text { Moderate improvement in fine lines, tactile } \\
\text { roughness, and skin tightness in both groups, } \\
\text { greater improvement in 3-hour group. }\end{array}$ \\
\hline $\begin{array}{l}\text { Ruiz-Rodriquez } \\
\text { et al }{ }^{194} \\
2007\end{array}$ & 4 & Split-face & $\begin{array}{l}\text { Fraxel }^{\circledR} \text { SR laser pretreatment } \\
\text { then MAL-PDT + red light } \\
\text { versus pretreatment only; } \\
3 \text { hours }\end{array}$ & $\begin{array}{l}2 \text { Fraxel SR laser } \\
(3 \text { weeks) then once } \\
\text { MAL-PDT; } 12 \text { weeks }\end{array}$ & $\begin{array}{l}\text { Greater improvement in pretreatment }+ \\
\text { MAL-PDT rather than pretreatment only } \\
\text { (not significant). }\end{array}$ \\
\hline $\begin{array}{l}\text { Gold et al }{ }^{169} \\
2006\end{array}$ & 13 & $\begin{array}{l}\text { Split-face, } \\
\text { prospective }\end{array}$ & $\begin{array}{l}20 \% \text { ALA-IPL versus IPL } \\
\left(550-570 \mathrm{~nm}, 34 \mathrm{~J} / \mathrm{cm}^{2}\right) \text { alone; } \\
30-60 \text { minutes }\end{array}$ & $\begin{array}{l}3 \times(1 \text { month }) \\
3 \text { months }\end{array}$ & $\begin{array}{l}\text { ALA-IPL > IPL alone. Crow's feet: } 55 \% \\
\text { ALA-IPL, } 29.5 \% \text { IPL alone. Tactile skin } \\
\text { roughness: } 55 \% \text { ALA-PDT-IPL, } 29.5 \% \text { IPL } \\
\text { alone. Mottled hyperpigmentation: } 60.3 \%> \\
37.2 \% \text { IPL alone. Telangiectasias: } 84.6 \% \\
\text { ALA-PDT- IPL, } 53.8 \% \text { IPL alone. }\end{array}$ \\
\hline $\begin{array}{l}\text { Dover et al }{ }^{195} \\
2005\end{array}$ & 20 & $\begin{array}{l}\text { Split-face, } \\
\text { prospective, } \\
\text { randomized }\end{array}$ & $\begin{array}{l}20 \% 5-A L A+I P L \text { versus IPL } \\
\left(5 I 5-1,200 \mathrm{~nm}, 23-28 \mathrm{~J} / \mathrm{cm}^{2}\right) \\
\text { alone; } 30-60 \text { minutes }\end{array}$ & $\begin{array}{l}3 \text { split face } \times \\
(3 \text { weeks }) \text { then } \\
2 \times \text { IPL only } \\
(3 \text { week }) ; \text { I month }\end{array}$ & $\begin{array}{l}\text { ALA-IPL }>\text { IPL alone. Photoaging scale: } 80 \% \\
\text { ALA-IPL, } 45 \% \text { IPL alone. Hyperpigmentation: } \\
85 \% \text { ALA-IPL, } 20 \% \text { IPL alone. Fine lines: } 60 \% \\
\text { ALA-IPL, } 25 \% \text { IPL alone. }\end{array}$ \\
\hline $\begin{array}{l}\text { Alster et al }{ }^{196} \\
2005\end{array}$ & 10 & Split-face & $\begin{array}{l}\text { 5-ALA-IPL versus IPL alone } \\
(560 \mathrm{~nm}) \text {; I hour }\end{array}$ & $\begin{array}{l}2 \times(4 \text { weeks }) \\
6 \text { months }\end{array}$ & $\begin{array}{l}\text { Higher clinical global improvement scores } \\
\text { (by photography) 5-ALA + IPL > IPL alone. }\end{array}$ \\
\hline
\end{tabular}

Note: Fraxel ${ }^{\circledR}$ (formerly Fraxel SR750, Reliant Technologies Inc, Palo Alto, CA, USA).

Abbreviations: PDT, photodynamic therapy; ALA, aminolevulinic acid; MAL, methyl aminolevulinate; IPL, intense pulsed light.

less than $2 \mathrm{~mm}$ in height. There was a 95\% (19/20) recurrence rate at 9-month follow-up. ${ }^{174}$ Furthermore, another study ( $\mathrm{n}=21$ ) showed improvement in post-surgical scar appearance, which directly correlated with the number of ALA/MAL-PDT sessions. ${ }^{175}$ PDT represents a promising, noninvasive treatment, but more definitive studies are required to elicit its role and the regimen required in the treatment of cicatrix.

\section{Concluding remarks}

PDT is a mainstay of treatment for actinic keratoses and superficial nonmelanoma skin cancers, and has been demonstrated to be an increasingly popular option for acne. With the advent of nanoemulsions and patch-ALA, recent advances have focused on improved vehicles and delivery. Improving standardization of ALA delivery and decreasing pain during the treatment are advances that will further popularize this modality. PDT is more frequently utilized in Europe as compared with the US. This discrepancy likely reflects the poor reimbursement rates for PDT in the US. Well controlled studies are needed to demonstrate the efficacy of PDT in order to justify its use, and hopefully convince insurance companies that this viable treatment option with a low side effect profile and high cosmetic outcome is worth 
investing in. The field of PDT will continue to expand as new photosensitizers emerge in the market. Finally, combination therapy, particularly with imiquimod, will be the new standard of care for PDT in patients with skin cancer.

\section{Disclosure}

The authors report no conflicts of interest in this work.

\section{References}

1. Calzavara-Pinton P, Arisi M, Sereni E, Ortel B. A critical reappraisal of off-label indications for topical photodynamic therapy with aminolevulinic acid and methylaminolevulinate. Rev Recent Clin Trials. 2010;5(2):112-116.

2. Darlenski R, Fluhr JW. Photodynamic therapy in dermatology: past, present, and future. J Biomed Opt. 2013;18(6):061208.

3. Dolmans DE, Fukumura D, Jain RK. Photodynamic therapy for cancer. Nat Rev Cancer. 2003;3(5):380-387.

4. Chaves YN, Torezan LA, Niwa AB, Sanches Junior JA, Festa Neto C. Pain in photodynamic therapy: mechanism of action and management strategies. An Bras Dermatol. 2012;87(4):521-526.

5. Morton CA, Szeimies RM, Sidoroff A, Braathen LR. European guidelines for topical photodynamic therapy part 1 : treatment delivery and current indications - actinic keratoses, Bowen's disease, basal cell carcinoma. J Eur Acad Dermatol Venereol. 2013;27(5):536-544.

6. Babilas P, Schreml S, Landthaler M, Szeimies RM. Photodynamic therapy in dermatology: state-of-the-art. Photodermatol Photoimmunol Photomed. 2010;26(3):118-132.

7. Webber J, Luo Y, Crilly R, Fromm D, Kessel D. An apoptotic response to photodynamic therapy with endogenous protoporphyrin in vivo. J Photochem Photobiol B. 1996;35(3):209-211.

8. Ackroyd R, Kelty C, Brown N, Reed M. The history of photodetection and photodynamic therapy. Photochem Photobiol. 2001;74(5): 656-669.

9. Taub AF. Photodynamic therapy in dermatology: history and horizons. J Drugs Dermatol. 2004;3(Suppl 1):S8-S25.

10. Dougherty TJ, Grindey GB, Fiel R, Weishaupt KR, Boyle DG. Photoradiation therapy. II. Cure of animal tumors with hematoporphyrin and light. J Natl Cancer Inst. 1975;55(1):115-121.

11. Josefsen LB, Boyle RW. Photodynamic therapy and the development of metal-based photosensitisers. Met Based Drugs. 2008;2008: 276109.

12. Noodt BB, Berg K, Stokke T, Peng Q, Nesland JM. Apoptosis and necrosis induced with light and 5-aminolaevulinic acid-derived protoporphyrin IX. Br J Cancer. 1996;74(1):22-29.

13. Gad F, Viau G, Boushira M, Bertrand R, Bissonnette R. Photodynamic therapy with 5-aminolevulinic acid induces apoptosis and caspase activation in malignant T cells. J Cutan Med Surg. 2001;5(1):8-13.

14. Kuzelová K, Grebenová D, Pluskalová M, Marinov I, Hrkal Z. Early apoptotic features of K562 cell death induced by 5 -aminolaevulinic acid-based photodynamic therapy. $J$ Photochem Photobiol B. 2004;73(1-2):67-78.

15. Mroz P, Yaroslavsky A, Kharkwal GB, Hamblin MR. Cell death pathways in photodynamic therapy of cancer. Cancers (Basel). 2011;3(2): 2516-2539.

16. Angell-Petersen E, Sørensen R, Warloe T, et al. Porphyrin formation in actinic keratosis and basal cell carcinoma after topical application of methyl 5-aminolevulinate. J Invest Dermatol. 2006;126(2): 265-271.

17. Peng Q, Soler AM, Warloe T, Nesland JM, Giercksky KE. Selective distribution of porphyrins in skin thick basal cell carcinoma after topical application of methyl 5-aminolevulinate. $J$ Photochem Photobiol B. 2001;62(3):140-145.

18. Fritsch C, Homey B, Stahl W, Lehmann P, Ruzicka T, Sies H. Preferential relative porphyrin enrichment in solar keratoses upon topical application of delta-aminolevulinic acid methylester. Photochem Photobiol. 1998;68(2):218-221.
19. Marjukka Suhonen T, Bouwstra JA, Urtti A. Chemical enhancement of percutaneous absorption in relation to stratum corneum structural alterations. J Control Release. 1999;59(2):149-161.

20. Matei C, Tampa M, Poteca T, et al. Photodynamic therapy in the treatment of basal cell carcinoma. J Med Life. 2013;6(1):50-54.

21. Gerritsen MJ, Smits T, Kleinpenning MM, van de Kerkhof PC, van Erp PE. Pretreatment to enhance protoporphyrin IX accumulation in photodynamic therapy. Dermatology. 2009;218(3):193-202.

22. Valentine RM, Ibbotson SH, Wood K, Brown CT, Moseley H. Modelling fluorescence in clinical photodynamic therapy. Photochem Photobiol Sci. 2013;12(1):203-213.

23. Di Venosa G, Hermida L, Batlle A, et al. Characterisation of liposomes containing aminolevulinic acid and derived esters. J Photochem Photobiol B. 2008;92(1):1-9.

24. Dirschka T, Radny P, Dominicus R, et al. Photodynamic therapy with BF-200 ALA for the treatment of actinic keratosis: results of a multicentre, randomized, observer-blind Phase III study in comparison with a registered methyl-5-aminolaevulinate cream and placebo. $\mathrm{Br} J$ Dermatol. 2012;166(1):137-146.

25. Passos SK, de Souza PE, Soares PK, et al. Quantitative approach to skin field cancerization using a nanoencapsulated photodynamic therapy agent: a pilot study. Clin Cosmet Investig Dermatol. 2013;6: $51-59$.

26. Wang YG, Kim H, Mun S, Kim D, Choi Y. Indocyanine green-loaded perfluorocarbon nanoemulsions for bimodal (19)F-magnetic resonance/ nearinfrared fluorescence imaging and subsequent phototherapy. Quant Imaging Med Surg. 2013;3(3):132-140.

27. Kuijpers DI, Thissen MR, Thissen CA, Neumann MH. Similar effectiveness of methyl aminolevulinate and 5-aminolevulinate in topical photodynamic therapy for nodular basal cell carcinoma. $J$ Drugs Dermatol. 2006;5(7):642-645.

28. Moloney FJ, Collins P. Randomized, double-blind, prospective study to compare topical 5-aminolaevulinic acid methylester with topical 5 -aminolaevulinic acid photodynamic therapy for extensive scalp actinic keratosis. Br J Dermatol. 2007;157(1):87-91.

29. Botto N, Rogers G. Nontraditional management of basal cell carcinoma. J Drugs Dermatol. 2013;12(5):525-532.

30. Pudroma X, Moan J, Ma LW, Iani V, Juzeniene A. A comparison of 5-aminolaevulinic acid- and its heptyl ester: dark cytotoxicity and protoporphyrin IX synthesis in human adenocarcinoma WiDr cells and in athymic nude mice healthy skin. Exp Dermatol. 2009;18(11): 985-987.

31. Barras A, Boussekey L, Courtade E, Boukherroub R. Hypericin-loaded lipid nanocapsules for photodynamic cancer therapy in vitro. Nanoscale. 2013;5(21):10562-10572.

32. Jang MS, Doh KS, Kang JS, Jeon YS, Suh KS, Kim ST. A comparative split-face study of photodynamic therapy with indocyanine green and indole-3-acetic acid for the treatment of acne vulgaris. Br J Dermatol. 2011;165(5):1095-1100.

33. Kim BJ, Lee HG, Woo SM, Youn JI, Suh DH. Pilot study on photodynamic therapy for acne using indocyanine green and diode laser. J Dermatol. 2009;36(1):17-21.

34. Ziolkowski P, Osiecka BJ, Oremek G, et al. Enhancement of photodynamic therapy by use of aminolevulinic acid/glycolic acid drug mixture. J Exp Ther Oncol. 2004;4(2):121-129.

35. Pierre MB, Ricci E Jr, Tedesco AC, Bentley MV. Oleic acid as optimizer of the skin delivery of 5-aminolevulinic acid in photodynamic therapy. Pharm Res. 2006;23(2):360-366.

36. Boddé HE, Roemelé PE, Star WM. Quantification of topically delivered 5-aminolevulinic acid by lontophoresis across ex vivo human stratum corneum. Photochem Photobiol. 2002;75(4):418-423.

37. Hashmi JT, Huang YY, Sharma SK, et al. Effect of pulsing in low-level light therapy. Lasers Surg Med. 2010;42(6):450-466.

38. Wiegell SR, Haedersdal M, Philipsen PA, Eriksen P, Enk CD, Wulf HC. Continuous activation of PpIX by daylight is as effective as and less painful than conventional photodynamic therapy for actinic keratoses; a randomized, controlled, single-blinded study. Br J Dermatol. 2008;158(4):740-746. 
39. Wiegell SR, Fabricius S, Stender IM et al. A randomized, multicentre study of directed daylight exposure times of $1(1 / 2)$ vs $2(1 / 2) \mathrm{h}$ in daylight-mediated photodynamic therapy with methyl aminolaevulinate in patients with multiple thin actinic keratoses of the face and scalp. $\mathrm{Br}$ J Dermatol. 2011;164(5):1083-1090.

40. Wiegell SR, Fabricius S, Gniadecka M, et al. Daylight-mediated photodynamic therapy of moderate to thick actinic keratoses of the face and scalp: a randomized multicentre study. Br J Dermatol. 2012;166(6): 1327-1332.

41. Wiegell SR, Wulf HC, Szeimies RM, et al. Daylight photodynamic therapy for actinic keratosis: an international consensus: International Society for Photodynamic Therapy in Dermatology. J Eur Acad Dermatol Venereol. 2012;26(6):673-679.

42. Wiegell SR, Fabricius S, Heydenreich J, et al. Weather conditions and daylight-mediated photodynamic therapy: protoporphyrin IX-weighted daylight doses measured in six geographical locations. Br J Dermatol. 2013;168(1):186-191.

43. Wiegell SR, Skødt V, Wulf HC. Daylight-mediated photodynamic therapy of basal cell carcinomas - an explorative study. J Eur Acad Dermatol Venereol. January 7, 2013. [Epub ahead of print.]

44. Dirschka T, Radny P, Dominicus R, et al. Long-term (6 and 12 months) follow-up of two prospective, randomized, controlled Phase III trials of photodynamic therapy with BF-200 ALA and methyl aminolaevulinate for the treatment of actinic keratosis. $\mathrm{Br} J$ Dermatol. 2013;168(4):825-836.

45. Braathen LR, Paredes BE, Saksela O, et al. Short incubation with methyl aminolevulinate for photodynamic therapy of actinic keratoses. J Eur Acad Dermatol Venereol. 2009;23(5):550-555.

46. Moseley H, Brancaleon L, Lesar AE, Ferguson J, Ibbotson SH. Does surface preparation alter ALA uptake in superficial non-melanoma skin cancer in vivo? Photodermatol Photoimmunol Photomed. 2008;24(2):72-75.

47. Torezan L, Chaves Y, Niwa A, Sanches JA Jr, Festa-Neto C, Szeimies RM. A pilot split-face study comparing conventional methyl aminolevulinatephotodynamic therapy (PDT) with microneedling-assisted PDT on actinically damaged skin. Dermatol Surg. 2013;39(8):1197-1201.

48. Togsverd-Bo K, Haak CS, Thaysen-Petersen D, Wulf HC, Anderson RR, Hædersdal M. Intensified photodynamic therapy of actinic keratoses with fractional $\mathrm{CO}_{2}$ laser: a randomized clinical trial Br J Dermatol. 2012;166(6):1262-1269.

49. Hong JS, Jung JY, Yoon JY, Suh DH. Acne treatment by methyl aminolevulinate photodynamic therapy with red light vs intense pulsed light. Int J Dermatol. 2013;52(5):614-619.

50. Clark C, Bryden A, Dawe R, Moseley H, Ferguson J, Ibbotson SH. Topical 5-aminolaevulinic acid photodynamic therapy for cutaneous lesions: outcome and comparison of light sources. Photodermatol Photoimmunol Photomed. 2003;19(3):134-141.

51. Gholam P, Kroehl V, Enk AH. Dermatology life quality index and side effects after topical photodynamic therapy of actinic keratosis Dermatology. 2013;226(3):253-259.

52. Orenstein A, Kostenich G, Tsur H, Kogan L, Malik Z. Temperature monitoring during photodynamic therapy of skin tumors with topical 5-aminolevulinic acid application. Cancer Lett. 1995;93(2):227-232.

53. Kasche A, Luderschmidt S, Ring J, Hein R. Photodynamic therapy induces less pain in patients treated with methyl aminolevulinate compared with aminolevulinic acid. J Drugs Dermatol. 2006;5(4):353-356.

54. Wiegell SR, Stender IM, Na R, Wulf HC. Pain associated with photodynamic therapy using 5-aminolevulinic acid or 5-aminolevulinic acid methylester on tape-stripped normal skin. Arch Dermatol. 2003;139(9):1173-1177.

55. Slaughter DP, Southwick HW, Smejkal W. Field cancerization in oral stratified squamous epithelium; clinical implications of multicentric origin. Cancer. 1953;6(5):963-968.

56. Lee Y, Baron ED. Photodynamic therapy: current evidence and applications in dermatology. Semin Cutan Med Surg. 2011;30(4):199-209.

57. Gupta AK, Paquet M, Villanueva E, Brintnell W. Interventions for actinic keratoses. Cochrane Database Syst Rev. 2012;12:CD004415.
58. Gupta AK, Paquet M. Network meta-analysis of the outcome 'participant complete clearance' in nonimmunosuppressed participants of eight interventions for actinic keratosis: a follow-up on a Cochrane review. Br J Dermatol. 2013;169(2):250-259.

59. Hauschild A, Popp G, Stockfleth E, et al. Effective photodynamic therapy of actinic keratoses on the head and face with a novel, self-adhesive 5-aminolaevulinic acid patch. Exp Dermatol. 2009;18(2):116-121.

60. Hauschild A, Stockfleth E, Popp G, et al. Optimization of photodynamic therapy with a novel self-adhesive 5-aminolaevulinic acid patch: results of two randomized controlled Phase III studies. Br J Dermatol. 2009;160(5):1066-1074.

61. Serra-Guillén C, Nagore E, Hueso L, et al. A randomized pilot comparative study of topical methyl aminolevulinate photodynamic therapy versus imiquimod 5\% versus sequential application of both therapies in immunocompetent patients with actinic keratosis: clinical and histologic outcomes. J Am Acad Dermatol. 2012;66(4):e131-e137.

62. Truchuelo M, Fernández-Guarino M, Fleta B, Alcántara J, Jaén P. Effectiveness of photodynamic therapy in Bowen's disease: an observational and descriptive study in 51 lesions. J Eur Acad Dermatol Venereol. 2012;26(7):868-874.

63. Bath-Hextall FJ, Matin RN, Wilkinson D, Leonardi-Bee J. Interventions for cutaneous Bowen's disease. Cochrane Database Syst Rev. 2013;6:CD007281.

64. Salim A, Leman JA, McColl JH, Chapman R, Morton CA. Randomized comparison of photodynamic therapy with topical 5-fluorouracil in Bowen's disease. Br J Dermatol. 2003;148(3):539-543.

65. Morton C, Horn M, Leman J, et al. Comparison of topical methyl aminolevulinate photodynamic therapy with cryotherapy or fluorouracil for treatment of squamous cell carcinoma in situ: results of a multicenter randomized trial. Arch Dermatol. 2006;142(6):729-735.

66. Perrett CM, McGregor JM, Warwick J, et al. Treatment of posttransplant premalignant skin disease: a randomized intrapatient comparative study of 5-fluorouracil cream and topical photodynamic therapy. Br J Dermatol. 2007;156(2):320-328.

67. de Haas ER, Sterenborg HJ, Neumann HA, Robinson DJ. Response of Bowen disease to ALA-PDT using a single and a 2-fold illumination scheme. Arch Dermatol. 2007;143(2):264-265.

68. Puizina-Ivić N, Zorc H, Vanjaka-Rogosić L, Mirić L, Persin A. Fractionated illumination improves the outcome in the treatment of precancerous lesions with photodynamic therapy. Coll Antropol. 2008;32 Suppl 2:67-73.

69. Thissen MR, Schroeter CA, Neumann HA. Photodynamic therapy with delta-aminolaevulinic acid for nodular basal cell carcinomas using a prior debulking technique. Br J Dermatol. 2000;142(2):338-339.

70. Morton CA, McKenna KE, Rhodes LE; British Association of Dermatologists Therapy Guidelines and Audit Subcommittee and the British Photodermatology Group. Guidelines for topical photodynamic therapy: update. Br J Dermatol. 2008;159(6):1245-1266.

71. Christensen E, Mørk C, Skogvoll E. High and sustained efficacy after two sessions of topical 5-aminolaevulinic acid photodynamic therapy for basal cell carcinoma: a prospective, clinical and histological 10-year follow-up study. Br J Dermatol. 2012;166(6):1342-1348.

72. Cosgarea R, Susan M, Crisan M, Senila S. Photodynamic therapy using topical 5-aminolaevulinic acid vs surgery for basal cell carcinoma. JEur Acad Dermatol Venereol. 2013;27(8):980-984.

73. Roozeboom MH, Aardoom MA, Nelemans PJ, et al. Fractionated 5-aminolevulinic acid photodynamic therapy after partial debulking versus surgical excision for nodular basal cell carcinoma: a randomized controlled trial with at least 5-year follow-up. J Am Acad Dermatol. 2013;69(2):280-287.

74. Osiecka B, Jurczyszyn K, Ziółkowski P. The application of levulanbased photodynamic therapy with imiquimod in the treatment of recurrent basal cell carcinoma. Med Sci Monit. 2012;18(2):PI5-PI9.

75. Basset-Seguin N, Ibbotson SH, Emtestam L, et al. Topical methyl aminolaevulinate photodynamic therapy versus cryotherapy for superficial basal cell carcinoma: a 5 year randomized trial. Eur J Dermatol. 2008;18(5):547-553. 
76. Rhodes LE, de Rie M, Enström Y, et al. Photodynamic therapy using topical methyl aminolevulinate vs surgery for nodular basal cell carcinoma: results of a multicenter randomized prospective trial. Arch Dermatol. 2004;140(1):17-23.

77. Szeimies RM, Ibbotson S, Murrell DF, et al. A clinical study comparing methyl aminolevulinate photodynamic therapy and surgery in small superficial basal cell carcinoma (8-20 mm), with a 12-month follow-up. J Eur Acad Dermatol Venereol. 2008;22(11):1302-1311.

78. Lehmann P. Methyl aminolaevulinate-photodynamic therapy: a review of clinical trials in the treatment of actinic keratoses and nonmelanoma skin cancer. Br J Dermatol. 2007;156(5):793-801.

79. Horn M, Wolf P, Wulf HC, et al. Topical methyl aminolaevulinate photodynamic therapy in patients with basal cell carcinoma prone to complications and poor cosmetic outcome with conventional treatment. Br J Dermatol. 2003;149(6):1242-1249.

80. Soler AM, Warloe T, Berner A, Giercksky KE. A follow-up study of recurrence and cosmesis in completely responding superficial and nodular basal cell carcinomas treated with methyl 5-aminolaevulinatebased photodynamic therapy alone and with prior curettage. $\mathrm{Br} J$ Dermatol. 2001;145(3):467-471.

81. Arits AH, Mosterd K, Essers BA, et al. Photodynamic therapy versus topical imiquimod versus topical fluorouracil for treatment of superficial basal-cell carcinoma: a single blind, non-inferiority, randomised controlled trial. Lancet Oncol. 2013;14(7):647-654.

82. Basset-Seguin N, Bissonnette R, Girard C, et al. Consensus recommendations for the treatment of basal cell carcinomas in Gorlin syndrome with topical methylaminolaevulinate-photodynamic therapy. J Eur Acad Dermatol Venereol. April 13, 2013. [Epub ahead of print.]

83. Chapas AM, Gilchrest BA. Broad area photodynamic therapy for treatment of multiple basal cell carcinomas in a patient with nevoid basal cell carcinoma syndrome. J Drugs Dermatol. 2006;5(Suppl 2):3-5.

84. Oseroff AR, Blumenson LR, Wilson BD, et al. A dose ranging study of photodynamic therapy with porfimer sodium (Photofrin) for treatment of basal cell carcinoma. Lasers Surg Med. 2006;38(5):417-426.

85. Coors EA, von den Driesch P. Topical photodynamic therapy for patients with therapy-resistant lesions of cutaneous T-cell lymphoma. $J$ Am Acad Dermatol. 2004;50(3):363-367.

86. Edström DW, Porwit A, Ros AM. Photodynamic therapy with topical 5-aminolevulinic acid for mycosis fungoides: clinical and histological response. Acta Derm Venereol. 2001;81(3):184-188.

87. Recio ED, Zambrano B, Alonso ML, et al. Topical 5-aminolevulinic acid photodynamic therapy for the treatment of unilesional mycosis fungoides: a report of two cases and review of the literature. Int $J$ Dermatol. 2008;47(4):410-413.

88. Debu A, Girard C, Kluger N, Guillot B, Dereure O. Topical methyl aminolaevulinate-photodynamic therapy in erosive facial mycosis fungoides. Br J Dermatol. 2010;163(4):884-885.

89. Markham T, Sheahan K, Collins P. Topical 5-aminolaevulinic acid photodynamic therapy for tumour-stage mycosis fungoides. $\mathrm{Br} \mathrm{J}$ Dermatol. 2001;144(6):1262-1263.

90. Quéreux G, Brocard A, Saint-Jean M, et al. Photodynamic therapy with methyl-aminolevulinic acid for paucilesional mycosis fungoides: a prospective open study and review of the literature. J Am Acad Dermatol. September 13, 2013. [Epub ahead of print.]

91. Calzavara-Pinton PG, Rossi MT, Sala R; Italian Group For Photodynamic Therapy. A retrospective analysis of real-life practice of off-label photodynamic therapy using methyl aminolevulinate (MALPDT) in 20 Italian dermatology departments. Part 2: Oncologic and infectious indications. Photochem Photobiol Sci. 2013;12(1): $158-165$.

92. Zane C, Venturini M, Sala R, Calzavara-Pinton P. Photodynamic therapy with methylaminolevulinate as a valuable treatment option for unilesional cutaneous T-cell lymphoma. Photodermatol Photoimmunol Photomed. 2006;22(5):254-258.

93. Mori M, Campolmi P, Mavilia L, Rossi R, Cappugi P, Pimpinelli N. Topical photodynamic therapy for primary cutaneous B-cell lymphoma: a pilot study. J Am Acad Dermatol. 2006;54(3):524-526.
94. Abels C. Targeting of the vascular system of solid tumours by photodynamic therapy (PDT). Photochem Photobiol Sci. 2004;3(8): 765-771.

95. Johnsson A, Kjeldstad B, Melø TB. Fluorescence from pilosebaceous follicles. Arch Dermatol Res. 1987;279(3):190-193.

96. Sakamoto FH, Torezan L, Anderson RR. Photodynamic therapy for acne vulgaris: a critical review from basics to clinical practice: part II. Understanding parameters for acne treatment with photodynamic therapy. J Am Acad Dermatol. 2010;63(2):195-211.

97. Sakamoto FH, Lopes JD, Anderson RR. Photodynamic therapy for acne vulgaris: a critical review from basics to clinical practice: Part I. Acne vulgaris: when and why consider photodynamic therapy? J Am Acad Dermatol. 2010;63(2):183-193.

98. Wiegell SR, Wulf HC. Photodynamic therapy of acne vulgaris using 5-aminolevulinic acid versus methyl aminolevulinate. $\mathrm{J} \mathrm{Am} \mathrm{Acad}$ Dermatol. 2006;54(4):647-651.

99. Hongcharu W, Taylor CR, Chang Y, Aghassi D, Suthamjariya K, Anderson RR. Topical ALA-photodynamic therapy for the treatment of acne vulgaris. J Invest Dermatol. 2000;115(2):183-192.

100. Kimura M, Itoh Y, Tokuoka Y, Kawashima N. Delta-aminolevulinic acid-based photodynamic therapy for acne on the body. J Dermatol. 2004;31(12):956-960.

101. Pollock B, Turner D, Stringer MR, et al. Topical aminolaevulinic acid-photodynamic therapy for the treatment of acne vulgaris: a study of clinical efficacy and mechanism of action. Br J Dermatol. 2004;151(3):616-622.

102. Itoh Y, Ninomiya Y, Tajima S, Ishibashi A. Photodynamic therapy of acne vulgaris with topical delta-aminolaevulinic acid and incoherent light in Japanese patients. Br J Dermatol. 2001;144(3):575-579.

103. Akaraphanth R, Kanjanawanitchkul W, Gritiyarangsan P. Efficacy of ALA-PDT vs blue light in the treatment of acne. Photodermatol Photoimmunol Photomed. 2007;23(5):186-190.

104. Choi MS, Yun SJ, Beom HJ, Park HR, Lee JB. Comparative study of the bactericidal effects of 5-aminolevulinic acid with blue and red light on Propionibacterium acnes. J Dermatol. 2011;38(7):661-666.

105. Hörfelt C, Funk J, Frohm-Nilsson M, Wiegleb Edström D, Wennberg AM. Topical methyl aminolaevulinate photodynamic therapy for treatment of facial acne vulgaris: results of a randomized, controlled study. Br J Dermatol. 2006;155(3):608-613.

106. Wiegell SR, Wulf HC. Photodynamic therapy of acne vulgaris using methyl aminolaevulinate: a blinded, randomized, controlled trial. Br J Dermatol. 2006;154(5):969-976.

107. Mavilia L, Malara G, Moretti G, Lo Re M, Puglisi Guerra A. Photodynamic therapy of acne using methyl aminolaevulinate diluted to $4 \%$ together with low doses of red light. Br J Dermatol. 2007;157(4):810-811.

108. Yeung CK, Shek SY, Yu CS, Kono T, Chan HH. Liposomeencapsulated $0.5 \% 5$-aminolevulinic acid with intense pulsed light for the treatment of inflammatory facial acne: a pilot study. Dermatol Surg. 2011;37(4):450-459.

109. Bissonnette R, Maari C, Nigen S, Provost N, Bolduc C. Photodynamic therapy with methylaminolevulinate $80 \mathrm{mg} / \mathrm{g}$ without occlusion improves acne vulgaris. J Drugs Dermatol. 2010;9(11):1347-1352.

110. Fadel M, Salah M, Samy N, Mona S. Liposomal methylene blue hydrogel for selective photodynamic therapy of acne vulgaris. J Drugs Dermatol. 2009;8(11):983-990.

111. de Leeuw J, van der Beek N, Bjerring P, Neumann HA. Photodynamic therapy of acne vulgaris using 5 -aminolevulinic acid $0.5 \%$ liposomal spray and intense pulsed light in combination with topical keratolytic agents. J Eur Acad Dermatol Venereol. 2010;24(4):460-469.

112. Oh SH, Ryu DJ, Han EC, Lee KH, Lee JH. A comparative study of topical 5-aminolevulinic acid incubation times in photodynamic therapy with intense pulsed light for the treatment of inflammatory acne. Dermatol Surg. 2009;35(12):1918-1926.

113. Ryou JH, Lee SJ, Park YM, Kim HO, Kim HS. Acne-photodynamic therapy with intra-lesional injection of 5-aminolevulinic acid. Photodermatol Photoimmunol Photomed. 2009;25(1):57-58. 
114. Holmes AD. Potential role of microorganisms in the pathogenesis of rosacea. J Am Acad Dermatol. September 5, 2013. [Epub ahead of print.]

115. Bryld LE, Jemec GB. Photodynamic therapy in a series of rosacea patients. J Eur Acad Dermatol Venereol. 2007;21(9):1199-1202.

116. Togsverd-Bo K, Wiegell SR, Wulf HC, Haedersdal M. Short and limited effect of long-pulsed dye laser alone and in combination with photodynamic therapy for inflammatory rosacea. J Eur Acad Dermatol Venereol. 2009;23(2):200-201.

117. Li X, Guo H, Tian Q, et al. Effects of 5-aminolevulinic acid-mediated photodynamic therapy on antibiotic-resistant staphylococcal biofilm: an in vitro study. J Surg Res. 2013;184(2):1013-1021.

118. Gilaberte Y, Frias MP, Rezusta A, Vera-Alvarez J. Photodynamic therapy with methyl aminolevulinate for resistant scalp folliculitis secondary to Demodex infestation. J Eur Acad Dermatol Venereol. 2009;23(6):718-719.

119. Bryld LE, Jemec GB. The bacterial flora of the skin surface following routine MAL-PDT. J Dermatolog Treat. 2006;17(4):222-223.

120. Schweiger ES, Riddle CC, Aires DJ. Treatment of hidradenitis suppurativa by photodynamic therapy with aminolevulinic acid: preliminary results. J Drugs Dermatol. 2011;10(4):381-386.

121. Gold M, Bridges TM, Bradshaw VL, Boring M. ALA-PDT and blue light therapy for hidradenitis suppurativa. J Drugs Dermatol. 2004;3(Suppl 1):S32-S35.

122. Sotiriou E, Apalla Z, Chovarda E, Panagiotidou D, Ioannides D. Photodynamic therapy with 5 -aminolevulinic acid in actinic cheilitis: an 18-month clinical and histological follow-up. J Eur Acad Dermatol Venereol. 2010;24(8):916-920.

123. Schroeter CA, Pleunis J, van Nispen tot Pannerden C, Reineke T, Neumann HA. Photodynamic therapy: new treatment for therapyresistant plantar warts. Dermatol Surg. 2005;31(1):71-75.

124. Stender IM, Lock-Andersen J, Wulf HC. Recalcitrant hand and foot warts successfully treated with photodynamic therapy with topical 5-aminolaevulinic acid: a pilot study. Clin Exp Dermatol. 1999;24(3): 154-159.

125. Gold MH, Pope A. Fractional resurfacing aiding photodynamic therapy of a recalcitrant plantar verruca: a case report and review of the literature. J Clin Aesthet Dermatol. 2008;1(1):30-33.

126. Karrer S, Szeimies RM, Abels C, Wlotzke U, Stolz W, Landthaler M. Epidermodysplasia verruciformis treated using topical 5-aminolaevulinic acid photodynamic therapy. Br J Dermatol. 1999;140(5): 935-938.

127. Nucci V, Torchia D, Cappugi P. Treatment of anogenital condylomata acuminata with topical photodynamic therapy: report of 14 cases and review. Int J Infect Dis. 2010;14 Suppl 3:e280-e282.

128. Wang J, Xu J, Chen J, et al. Successful photodynamic therapy with topical 5-aminolevulinic acid for five cases of cervical intraepithelial neoplasia. Arch Gynecol Obstet. 2010;282(3):307-312.

129. Ross EV, Romero R, Kollias N, Crum C, Anderson RR. Selectivity of protoporphyrin IX fluorescence for condylomata after topical application of 5-aminolaevulinic acid: implications for photodynamic treatment. Br J Dermatol. 1997;137(5):736-742.

130. Fehr MK, Chapman CF, Krasieva T, et al. Selective photosensitizer distribution in vulvar condyloma acuminatum after topical application of 5-aminolevulinic acid. Am J Obstet Gynecol. 1996;174(3): 951-957.

131. Istomin YP, Lapzevich TP, Chalau VN, Shliakhtsin SV, Trukhachova TV. Photodynamic therapy of cervical intraepithelial neoplasia grades II and III with Photolon. Photodiagnosis Photodyn Ther. 2010;7(3):144-151.

132. Ichimura H, Yamaguchi S, Kojima A, et al. Eradication and reinfection of human papillomavirus after photodynamic therapy for cervical intraepithelial neoplasia. Int J Clin Oncol. 2003;8(5): 322-325.

133. Chen K, Chang BZ, Ju M, Zhang XH, Gu H. Comparative study of photodynamic therapy vs $\mathrm{CO}_{2}$ laser vaporization in treatment of condylomata acuminata: a randomized clinical trial. Br J Dermatol. 2007;156(3):516-520.
134. Gold MH, Boring MM, Bridges TM, Bradshaw VL. The successful use of ALA-PDT in the treatment of recalcitrant molluscum contagiosum. J Drugs Dermatol. 2004;3(2):187-190.

135. Rossi R, Bruscino N, Ricceri F, Grazzini M, Dindelli M, Lotti T. Photodynamic treatment for viral infections of the skin. G Ital Dermatol Venereol. 2009;144(1):79-83.

136. Szeimies RM, Schleyer V, Moll I, Stocker M, Landthaler M, Karrer S. Adjuvant photodynamic therapy does not prevent recurrence of condylomata acuminata after carbon dioxide laser ablation - a Phase III, prospective, randomized, bicentric, double-blind study. Dermatol Surg. 2009;35(5):757-764.

137. Sotiriou E, Panagiotidou D, Ioannides D. 5-Aminolevulininic acid photodynamic therapy treatment for tinea cruris caused by Trichophyton rubrum: report of 10 cases. J Eur Acad Dermatol Venereol. 2009;23(3):341-342.

138. Sotiriou E, Koussidou T, Patsatsi A, Apalla Z, Ioannides D. 5-Aminolevulinic acid-photodynamic treatment for dermatophytic tinea pedis of interdigital type: a small clinical study. J Eur Acad Dermatol Venereol. 2009;23(2):203-204.

139. Calzavara-Pinton PG, Venturini M, Capezzera R, Sala R, Zane C. Photodynamic therapy of interdigital mycoses of the feet with topical application of 5-aminolevulinic acid. Photodermatol Photoimmunol Photomed. 2004;20(3):144-147.

140. Sotiriou E, Koussidou-Eremonti T, Chaidemenos G, Apalla Z, Ioannides D. Photodynamic therapy for distal and lateral subungual toenail onychomycosis caused by Trichophyton rubrum: preliminary results of a single-centre open trial. Acta Derm Venereol. 2010;90(2):216-217.

141. Gilaberte Y, Aspiroz C, Martes MP, Alcalde V, Espinel-Ingroff A, Rezusta A. Treatment of refractory fingernail onychomycosis caused by nondermatophyte molds with methylaminolevulinate photodynamic therapy. J Am Acad Dermatol. 2011;65(3):669-671.

142. Watanabe D, Kawamura C, Masuda Y, Akita Y, Tamada Y, Matsumoto Y. Successful treatment of toenail onychomycosis with photodynamic therapy. Arch Dermatol. 2008;144(1):19-21.

143. Smijs TG, Bouwstra JA, Talebi M, Pavel S. Investigation of conditions involved in the susceptibility of the dermatophyte Trichophyton rubrum to photodynamic treatment. J Antimicrob Chemother. 2007;60(4):750-759

144. Smijs TG, Pavel S. The susceptibility of dermatophytes to photodynamic treatment with special focus on Trichophyton rubrum. Photochem Photobiol. 2011;87(1):2-13

145. Abadi D, Zderic V. Ultrasound-mediated nail drug delivery system. J Ultrasound Med. 2011;30(12):1723-1730.

146. Amichai B, Nitzan B, Mosckovitz R, Shemer A. Iontophoretic delivery of terbinafine in onychomycosis: a preliminary study. $\mathrm{Br} J$ Dermatol. 2010;162(1):46-50.

147. Silva AP, Kurachi C, Bagnato VS, Inada NM. Fast elimination of onychomycosis by hematoporphyrin derivative-photodynamic therapy. Photodiagnosis Photodyn Ther. 2013;10(3):328-330.

148. Sohl S, Kauer F, Paasch U, Simon JC. Photodynamic treatment of cutaneous leishmaniasis. J Dtsch Dermatol Ges. 2007;5(2): 128-130.

149. Asilian A, Davami M. Comparison between the efficacy of photodynamic therapy and topical paromomycin in the treatment of Old World cutaneous leishmaniasis: a placebo-controlled, randomized clinical trial. Clin Exp Dermatol. 2006;31(5):634-637.

150. Gardlo K, Horska Z, Enk CD, et al. Treatment of cutaneous leishmaniasis by photodynamic therapy. J Am Acad Dermatol. 2003;48(6) 893-896.

151. González U, Pinart M, Reveiz L, Alvar J. Interventions for Old World cutaneous leishmaniasis. Cochrane Database Syst Rev. 2008;4: CD005067.

152. Poeppl W, Oeser C, Grabmeier-Pfistershammer K, Walochnik J, Burgmann $\mathrm{H}$. Clinical findings and management of imported cutaneous leishmaniasis: report of 14 cases from Austria. Travel Med Infect Dis. 2013;11(2):90-94. 
153. Darras-Vercambre S, Carpentier O, Vincent P, Bonnevalle A, Thomas P. Photodynamic action of red light for treatment of erythrasma: preliminary results. Photodermatol Photoimmunol Photomed. 2006;22(3):153-156.

154. Luderschmidt C, Plewig G. Circumscribed sebaceous gland hyperplasia: autoradiographic and histoplanimetric studies. J Invest Dermatol. 1978;70(4):207-209.

155. Plewig G, Kligman AM. Proliferative activity of the sebaceous glands of the aged. J Invest Dermatol. 1978;70(6):314-317.

156. Fisher GJ, Kang S, Varani J, et al. Mechanisms of photoaging and chronological skin aging. Arch Dermatol. 2002;138(11):1462-1470.

157. Karrer S, Bosserhoff AK, Weiderer P, Landthaler M, Szeimies RM. Keratinocyte-derived cytokines after photodynamic therapy and their paracrine induction of matrix metalloproteinases in fibroblasts. $\mathrm{Br} J$ Dermatol. 2004;151(4):776-783.

158. Marmur ES, Phelps R, Goldberg DJ. Ultrastructural changes seen after ALA-IPL photorejuvenation: a pilot study. J Cosmet Laser Ther. 2005;7(1):21-24.

159. Orringer JS, Hammerberg C, Hamilton T, et al. Molecular effects of photodynamic therapy for photoaging. Arch Dermatol. 2008;144(10): 1296-1302.

160. Orringer JS, Voorhees JJ, Hamilton T, et al. Dermal matrix remodeling after nonablative laser therapy. J Am Acad Dermatol. 2005; 53(5):775-782.

161. Gold MH. The evolving role of aminolevulinic acid hydrochloride with photodynamic therapy in photoaging. Cutis. 2002; 69(Suppl 6):8-13.

162. Clementoni MT, B-Roscher M, Munavalli GS. Photodynamic photorejuvenation of the face with a combination of microneedling, red light, and broadband pulsed light. Lasers Surg Med. 2010;42(2):150-159.

163. Touma D, Yaar M, Whitehead S, Konnikov N, Gilchrest BA. A trial of short incubation, broad-area photodynamic therapy for facial actinic keratoses and diffuse photodamage. Arch Dermatol. 2004;140(1): 33-40.

164. Zane C, Capezzera R, Sala R, Venturini M, Calzavara-Pinton P. Clinical and echographic analysis of photodynamic therapy using methylaminolevulinate as sensitizer in the treatment of photodamaged facial skin. Lasers Surg Med. 2007;39(3):203-209.

165. Ruiz-Rodríguez R, López L, Candelas D, Pedraz J. Photorejuvenation using topical 5-methyl aminolevulinate and red light. J Drugs Dermatol. 2008;7(7):633-637.

166. Sanclemente G, Medina L, Villa JF, Barrera LM, Garcia HI. A prospective split-face double-blind randomized placebo-controlled trial to assess the efficacy of methyl aminolevulinate + red-light in patients with facial photodamage. J Eur Acad Dermatol Venereol. 2011;25(1):49-58.

167. Palm MD, Goldman MP. Safety and efficacy comparison of blue versus red light sources for photodynamic therapy using methyl aminolevulinate in photodamaged skin. J Drugs Dermatol. 2011;10(1): 53-60.

168. Dover JS, Bhatia AC, Stewart B, Arndt KA. Topical 5-aminolevulinic acid combined with intense pulsed light in the treatment of photoaging. Arch Dermatol. 2005;141(10):1247-1252.

169. Gold MH, Bradshaw VL, Boring MM, Bridges TM, Biron JA. Split-face comparison of photodynamic therapy with 5-aminolevulinic acid and intense pulsed light versus intense pulsed light alone for photodamage. Dermatol Surg. 2006;32(6):795-801.

170. Babilas P, Knobler R, Hummel S, et al. Variable pulsed light is less painful than light-emitting diodes for topical photodynamic therapy of actinic keratosis: a prospective randomized controlled trial. $\mathrm{Br} \mathrm{J}$ Dermatol. 2007;157(1):111-117.

171. Karrer S, Bosserhoff AK, Weiderer P, Landthaler M, Szeimies RM. Influence of 5-aminolevulinic acid and red light on collagen metabolism of human dermal fibroblasts. J Invest Dermatol. 2003;120(2):325-331.

172. Campbell SM, Tyrrell J, Marshall R, Curnow A. Effect of MALphotodynamic therapy on hypertrophic scarring. Photodiagnosis Photodyn Ther. 2010;7(3):183-188.
173. Bruscino N, Lotti T, Rossi R. Photodynamic therapy for a hypertrophic scarring: a promising choice. Photodermatol Photoimmunol Photomed. 2011;27(6):334-335.

174. Ud-Din S, Thomas G, Morris J, Bayat A. Photodynamic therapy: an innovative approach to the treatment of keloid disease evaluated using subjective and objective non-invasive tools. Arch Dermatol Res. 2013;305(3):205-214.

175. Sakamoto FH, Izikson L, Tannous Z, Zurakowski D, Anderson RR. Surgical scar remodelling after photodynamic therapy using aminolaevulinic acid or its methylester: a retrospective, blinded study of patients with field cancerization. Br J Dermatol. 2012;166(2): 413-416.

176. Pinto C, Schafer F, Orellana JJ, Gonzalez S, Hasson A. Efficacy of red light alone and methyl-aminolaevulinate-photodynamic therapy for the treatment of mild and moderate facial acne. Indian J Dermatol Venereol Leprol. 2013;79:77-82.

177. Shaaban D, Abdel-Samad Z, El-Khalawany M. Photodynamic therapy with intralesional 5-aminolevulinic acid and intense pulsed light versus intense pulsed light alone in the treatment of acne vulgaris: a comparative study. Dermatol Ther. 2012;25:86-91.

178. Haedersdal M, Togsverd-Bo K, Wiegell SR, Wulf HC. Long-pulsed dye laser versus long-pulsed dye laser-assisted photodynamic therapy for acne vulgaris: A randomized controlled trial. J Am Acad Dermatol. 2008;58:387-394.

179. Sadick N. An open-label, split-face study comparing the safety and efficacy of levulan kerastick (aminolevulonic acid) plus a $532 \mathrm{~nm}$ KTP laser to a $532 \mathrm{~nm}$ KTP laser alone for the treatment of moderate facial acne. J Drugs Dermatol. 2010;9:229-233.

180. Barolet D, Boucher A. Radiant near infrared light emitting Diode exposure as skin preparation to enhance photodynamic therapy inflammatory type acne treatment outcome. Lasers Surg Med. 2010;42:171-178.

181. Yeung CK, Shek SY, Bjerring P, Yu CS, Kono t, Chang HH. A comparative study of intense pulsed light alone and its combination with photodynamic therapy for the treatment of facial acne in Asian skin. Lasers Surgery Med. 2007;39:1-6.

182. Rojanamatin J, Choawawanich P. Treatment of inflammatory facial acne vulgaris with intense pulsed light and short contact of topical 5-aminolevulinic acid: a pilot study. Dermatol Surg. 2006;32:991-996; discussion 996-997.

183. Santos MA, Belo, VG, Santos G. Effectiveness of photodynamic therapy with topical 5-aminolevulinic acid and intense pulsed light versus intense pulsed light alone in the treatment of acne vulgaris: comparative study. Dermatol Surg. 2005;31:910-915.

184. Hong SB, Lee MH. Topical aminolevulinic acid-photodynamic therapy for the treatment of acne vulgaris. Photodermatol Photoimmunol Photomed. 2005;21:322-325.

185. Goldman MP, Boyce SM. A single-center study of aminolevulinic acid and 417 NM photodynamic therapy in the treatment of moderate to severe acne vulgaris. J of Drugs Dermatol. 2003;2:393-396.

186. Papageorgiou P, Katsambas A, Chu A. Phototherapy with blue $(415 \mathrm{~nm})$ and red $(660 \mathrm{~nm})$ light in the treatment of acne vulgaris. Br J Dermatol. 2000;142:973-978.

187. Kwon SH, Jeaong MY, Park KC, Youn SW, Huh CH, Na JI. A new therapeutic option for facial seborrhoeic dermatitis: indole-3acetic acid photodynamic therapy. J Eur Acad Dermatol Venereol. 2013;28(1):94-99.

188. Huh SY, Na JI, Huh CH, Park KC. The effect of photodynamic therapy using indole-3-acetic Acid and green light on acne vulgaris. Ann Dermatol. 2012;24:56-60.

189. Na JI, Kim SY, Kim JH, Youn SW, Huh CH, Park CH. Indole-3-acetic acid: a potential new photosensitizer for photodynamic therapy of acne vulgaris. Lasers Surg Med. 2011;43:200-205.

190. Haddad A, Santos ID, Gragnani A, Ferreira LM. The effect of increasing fluence on the treatment of actinic keratosis and photodamage by photodynamic therapy with 5-aminolevulinic acid and intense pulsed light. Photomed Laser Surg. 2011;29:427-432. 
191. Xi Z, Shuxian Y, Zhong L, et al. Topical 5-aminolevulinic acid with intense pulsed light versus intense pulsed light for photodamage in Chinese patients. Dermatolog Surg. 2011;37:31-40.

192. Kosaka S, Yasumoto M, Akilov OE, Hasan T, Kawana S. Comparative split-face study of 5-aminolevulinic acid photodynamic therapy with intense pulsed light for photorejuvenation of Asian skin. J Dermatol. 2010;37:1005-1010.

193. Bjerring P, Christiansen K, Troilius A, Bekhor P, de Leeuw J. Skin fluorescence controlled photodynamic photorejuvenation (wrinkle reduction). Lasers Surg Med. 2009;41:327-336.
194. Ruiz-Rodriguez R, Lopez L, Candelas D, Zelickson B. Enhanced efficacy of photodynamic therapy after fractional resurfacing: fractional photodynamic rejuvenation. J Drugs Dermatol. 2007;6:818-820.

195. Dover JS, Bhatia AC, Stewart B, Arndt KA. Topical 5-aminolevulinic acid combined with intense pulsed light in the treatment of photoaging. Arch Dermatol. 2005;141:1247-1252.

196. Alster TS, Tanzi EL, Welsh EC. Photorejuvenation of facial skin with topical 20\% 5-aminolevulinic acid and intense pulsed light treatment: a split-face comparison study. J Drugs Dermatol. 2005;4:35-38.

\section{Publish your work in this journal}

Clinical, Cosmetic and Investigational Dermatology is an international, peer-reviewed, open access, online journal that focuses on the latest clinical and experimental research in all aspects of skin disease and cosmetic interventions. All areas of dermatology will be covered; contributions will be welcomed from all clinicians and basic science researchers globally. This journal is indexed on CAS. The manuscript management system is completely online and includes a very quick and fair peer-review system, which is all easy to use. Visit http://www.dovepress.com/testimonials.php to read real quotes from published authors.

Submit your manuscript here: http://www.dovepress.com/clinical-cosmetic-and-investigational-dermatology-journal 